\title{
Gut Microbiota, Its Role in Induction of Alzheimer's Disease Pathology, and Possible Therapeutic Interventions: Special Focus on Anthocyanins
}

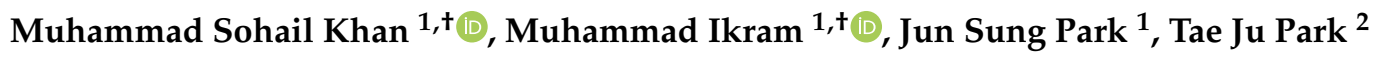 \\ and Myeong Ok Kim ${ }^{1, *}$ \\ 1 Division of Applied Life Science (BK 21), College of Natural Sciences, Gyeongsang National University, \\ Jinju 52828, Korea; Sohail.bannu@gnu.ac.kr (M.S.K.); qazafi417@gnu.ac.kr (M.I.); jsp@gnu.ac.kr (J.S.P.) \\ 2 Paul O'Gorman Leukaemia Research, Centre Institute of Cancer, Sciences University of Glasgow, \\ 07476575394 Glasgow, UK; 2358860P@student.gla.ac.uk \\ * Correspondence: mokim@gnu.ac.kr; Tel.: +82-55-772-1345; Fax: +82-55-772-2656 \\ + These authors contributed equally to this paper.
}

Received: 29 February 2020; Accepted: 31 March 2020; Published: 1 April 2020

\begin{abstract}
The human gut is a safe environment for several microbes that are symbiotic and important for the wellbeing of human health. However, studies on gut microbiota in different animals have suggested that changes in the composition and structure of these microbes may promote gut inflammation by releasing inflammatory cytokines and lipopolysaccharides, gut-wall leakage, and may affect systemic inflammatory and immune mechanisms that are important for the normal functioning of the body. There are many factors that aid in the gut's dysbiosis and neuroinflammation, including high stress levels, lack of sleep, fatty and processed foods, and the prolonged use of antibiotics. These neurotoxic mechanisms of dysbiosis may increase susceptibility to Alzheimer's disease (AD) and other neurodegenerative conditions. Therefore, studies have recently been conducted to tackle AD-like conditions by specifically targeting gut microbes that need further elucidation. It was suggested that gut dyshomeostasis may be regulated by using available options, including the use of flavonoids such as anthocyanins, and restriction of the use of high-fatty-acid-containing food. In this review, we summarize the gut microbiota, factors promoting it, and possible therapeutic interventions especially focused on the therapeutic potential of natural dietary polyflavonoid anthocyanins. Our study strongly suggests that gut dysbiosis and systemic inflammation are critically involved in the development of neurodegenerative disorders, and the natural intake of these flavonoids may provide new therapeutic opportunities for preclinical or clinical studies.
\end{abstract}

Keywords: natural polyflavonoids; gut dysbiosis; systemic inflammation; neuroinflammation; memory impairment; Alzheimer's disease

\section{Introduction}

The microbial population living in human and animal intestines is termed as the gut microbiota (formerly called gut flora). Gut microbiota are trillions of micro-organisms, including at least 1000 different species of known bacteria with more than three million genes [1]. The interaction between human health and the gut microbiota is well-documented [2]. The gut microbiota comprises two phyla, Bacteroidetes and Firmicutes. At the embryonic stage, the gut microbiota appears disorganized, while by the age of three, it starts to look similar to adult flora [3]. Several main microbiota functions have been explored, including the synthesis of amino acids and vitamins that play a major role in the circulation of steroid molecules (including bile acids and sex hormones), boosting the immune system and production of different bioactive compounds [4,5]. 
In this comprehensive review, we summarize the current research, highlighting the role of the gut microbiota in the pathogenesis of neuroinflammation and AD-like pathologies. The literature search was comprehensive, including both published and unpublished articles. We documented the search process, kept track of the decisions that were made for each article, and screened and extracted the conclusions. Moreover, we summarized all current research from more than 350 research and review articles, showing the interaction between gut microbiota and neurocognitive function. In summary, our findings suggest that gut microbiota have a significant impact on the pathogenesis of Alzheimer's disease, which may be significantly delayed with the administration of anthocyanin.

\subsection{Normal Gut-Microbiota Functions in Human Body}

Colonic bacteria can ferment complex carbohydrate-yielding short-chain fatty acids (SCFAs) in which propionate, butyrate, and acetate are predominantly found in the gastrointestinal tract (GI), with a ratio of 1:1:3, respectively, performing different cellular functions, such as gene expression, chemotaxis, differentiation, and proliferation. Acetate is generated by most gut anaerobes, whereas propionate and butyrate are produced by different classes of gut bacteria following distinct molecular pathways. Butyrate is generated from carbohydrates via the acetoacetyl-CoA and glycolytic pathway, whereas propionate is formed from two pathways, the succinate or propanediol pathway [6-11].

Propionate gluconeogenesis can be stimulated by the liver, while acetate and butyrate are lipogenic. Propionate and butyrate are histone deacetylase (HDAC) inhibitors, which epigenetically modulate the expression of certain important genes. SCFAs confer a key role in the regulation of immunity and inflammatory conditions. They also affect the release of cytokines, for example, by activating the release of interleukin IL-18, that is involved in the restoration and preservation of the epithelial structure. SCFAs were shown to regulate appetite and energy intake via various mechanisms [12-19].

GI microbes are also helpful in the synthesis of pivotal vitamins that cannot be produced by the host organisms. Vitamin B12, which is crucial for the body, is produced by lactic acid bacteria and is not synthesized by animals and plants. Other vitamins, such as folate that regulates the metabolic processes of the hosts, including DNA synthesis and repair, are produced by Bifidobacteria. A major immune shortage shown by germfree animals is the lack of CD4+ T-cell levels. This dearth can be recovered by the administration of polysaccharide A to germfree mice from the capsule of Bacteroides fragilis. This mechanism is conducted through pattern-recognition receptors (PRRs), such as toll- or NOD-like receptors, which recognize molecules that are induced by intestinal microbiota. These processes may attenuate certain inflammatory gut diseases by boosting the beneficial suppression of pathogenic bacteria, or regulating immune cells or PRRs [20,21]. In Crohn's disease, individuals display mucosal dysbiosis, which may be pointed out by the reduced diversity of main microbes and F. prausnitzii [22-29].

Studies have suggested that $F$. prausnitzii contains an anti-inflammatory protein that inhibits the nuclear factor- $\mathrm{kB}$ (NF- $\kappa \mathrm{B}$ ) pathway in intestinal epithelial cells in animals. NF- $\kappa B$ represents a family of inducible transcription factors, that regulate a large number of genes involved in inflammatory processes. This family is composed of five structurally related members that mediate the transcription of target genes by binding to a specific DNA element, the $\mathrm{kB}$ enhancer, as various hetero- or homodimers [30]. Normally, NF-kB is locked in the cytoplasm by an inhibitory protein of the I $\kappa B$ family. Upon activation, I $\kappa B$ is phosphorylated by the I $\kappa B$ kinase complex (IKK), before undergoing degradation by the proteasome. Then, free NF- $\mathrm{KB}$ translocates to the nucleus to turn on a large number of genes involved in proinflammatory processes at the site of tissue damage [31]. Different studies have suggested that the gut microbiota plays a role in the inhibition of NF- $\mathrm{kB}[32,33]$. Moreover, Salmonella typhimurium and Clostridium difficile utilize sialic acid, released by the gut microbiota, which favors their expansion in the gut [34-39]. The GI microbiota, through its metabolites, promotes the production of different antimicrobials, which include antimicrobial proteins (AMPs) such as cathelicidins and C-type lectins. Other mechanisms through 
which the gut microbiota can overcome pathogen growth are by promoting mucosal secretory IgA (SIgA). Moreover, pattern-recognition-receptor-microbe-associated-molecular-pattern (PRR-MAMP) interactions regulate several signaling tools that are crucial for promoting mucosal-barrier function and the production of AMPs, thus adding to host defense against pathogenic microbes [3,40-43].

\subsection{Dysbiosis and Its Pathogenesis Factors}

Dysbiosis is a term for a microbial imbalance inside the body, such as an impaired microbiota. There are many factors involved in dysbiosis that are given in Figure 1 [44].

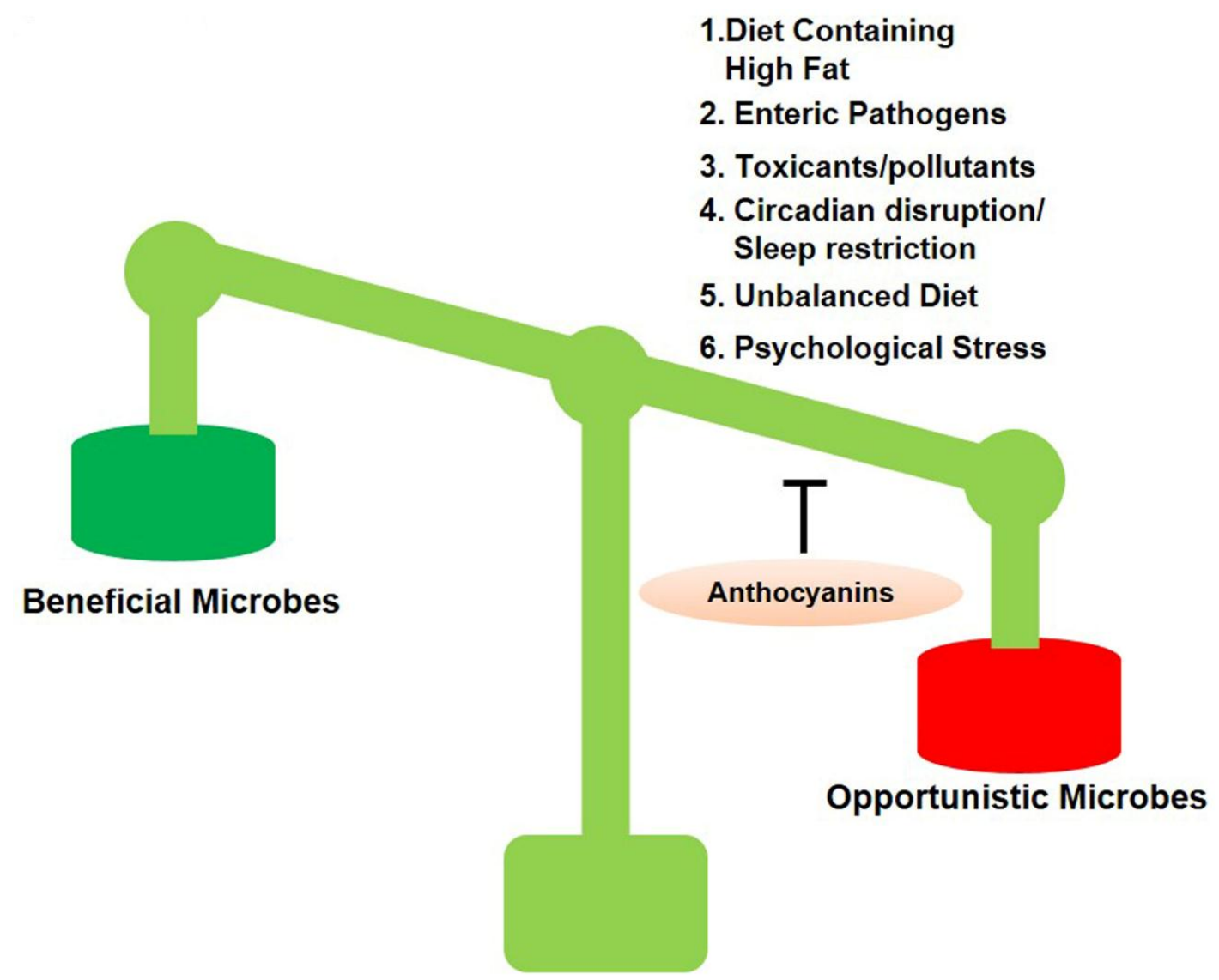

Figure 1. Anthocyanins switch population of opportunistic bacteria. Several factors provide opportunities to harmful microbes.

\subsubsection{Congenital Factors}

The microbial population can be affected by numerous factors, including mode of birth, nutrition, antibiotic exposure, stress, age, and degree of hygiene. For example, babies born through the vagina acquire the mother's vaginal microbial flora, including Escherichia coli, Lactobacillus, Bifidobacterium, and Bacteroides. Those born via Cesarean section, on the other hand, have a high risk of skin-related bacterial invasion, including Staphylococcus species that continue throughout infancy [45-52].

\subsubsection{Dietary Factors}

The effects of diet on the structure of gut microbes have been evaluated during the initial phase of colonization, as breastfed children have a greater number of Bifidobacteria spp, while formula-milk-fed children have higher levels of Bacteroides spp. Generally, a change in diet could induce $57 \%$ of total changes in gut microbiota, whereas congenital changes account for less than $12 \%$, showing that diet has a prominent role in the structuring of the gut microbiota. The Western diet, which is rich in sugar and fat, causes dysbiosis, and affects the GI tract and the immune system [53-55]. The effects of a high-fat 
diet (HFD) on mice were also evaluated, where they were fed with a HFD for three months and showed a decline in the growth of Bacteroidetes, while the levels of Firmicutes, Proteobacteria, and Actinobacteria were markedly upregulated [56-61].

\subsubsection{Effects of Chemical Exposure on Gut Microbiota}

It was previously concluded that exposure to chemicals causes marked dysbiosis in the gut, which includes the augmented production of the Firmicutes phylum and reduced Bacteroidetes production. Similarly, the chronic administration of corticosterone causes gut dysbiosis. Furthermore, recent studies have suggested that the lack of intestinal alkaline phosphatase (IAP) induces dysbiosis, and elevates the inflammation and penetrability of the intestinal lining of newborns [62-66].

\subsubsection{Effects of General Stress on Gut Microbiota}

Stress is a disturbance in body homeostasis, due to different kinds of factors, such as psychological and environmental stimuli, and physical stress, which provoke physiological and behavioral responses to reinstate homeostasis. Stress has a variety of biological effects, such as modulation of microbes in the GI tract. [67-74]. Here, we present recent studies associated with stress-induced changes in GI microbiota structure and composition. Stress types include sleep deprivation, psychological stress, circadian disturbance, environmental pathogens, environmental stress, pollutants, and diet, which were selected for their direct effect on environmental physiology and military personnel [75-79].

\subsubsection{Mental Stress and Gut Microbiota}

Physiological stress may be induced by different means, including social deprivation and water restraint. These induce a disturbance in the body that causes inflammation, modulates immunity, alters GI function, and produces anxiety-like behaviors. From a military perspective, social defeat stress (SDS) is the most accepted model [80-85]. Using the SDS model in a study, $2 \mathrm{~h}$ SDS was enough to change mucosa-related microbes in mice, reducing Lactobacillus reuteri. When they were repeatedly exposed for $2 \mathrm{~h}$ over 6 days, this caused the higher attenuation of Lactobacillus. The relationship between gut, brain, and gut microbiota is bidirectional, where stress-triggered activation of the sympathetic nervous system (SNS) and the hypothalamic-pituitary-adrenal (HPA) axis affects gastrointestinal (GI)-tract microbes. Later, all these affect the central nervous system, either through the enteric nervous system, via spinal and vagal nerves, or via blood circulation when they gain entry to the blood stream and cross the blood-brain barrier [86-89].

\subsubsection{Altitude and Temperature Effects on Normal Gut Microbiota}

It is commonly reported that the consequences of high altitude $(2500 \mathrm{~m})$ may affect the GI system (GIS). The symptoms that were observed because of hypobaric hypoxia are loss of appetite, indigestion, nausea, vomiting, gas, and abdominal pain. It has been reported that low oxygen delivery to the GI affects motility, because intestinal epithelia cells need oxygen-saturated blood for their normal physiological functions. An increase in the number of proinflammatory Enterobacteriaceae with increased inflammation and a decrease in the number of Bifidobacteria was found during a trip to Himalaya. Furthermore, it has been demonstrated that soldiers working or training at $3505 \mathrm{~m}$ altitude may decrease aerobic counts, while increasing beneficial and harmful micro-organisms [90-95].

A recent study showed that acute cold promotes alteration in murine gut microbiota [96-100]. Several studies indicated that the effect of cold on the human gut microbiota could be useful by promoting cold tolerance, which needs more exploration [101-103].

\subsubsection{Intestinal Infection (Enteric Pathogens) Accelerates Gut Dysbiosis and Alters} Gastrointestinal-Wall Integrity

A major type of diarrhea is called traveler's diarrhea (TD), which commonly occurs in military personnel and is caused by enteroaggregative and enterotoxigenic E. coli Salmonella spp, 
Shigella, and Campylobacter jejuni. These agents cause diarrheal infections through the physical disruption of the gut barrier and immune-system disturbance, which leads to disturbing the gastric environment [104-110]. Some medically recommended antibiotics that are used for the treatment of infectious diarrhea and TD are azithromycin; levofloxacin enables the growth of opportunistic pathogens [111-116].

1.2.8. Environmental Pollution and Toxins Affect Animal Health and Increase the Number of Opportunistic Gut Microbes

Industrial chemicals and toxic industrial materials make the environment and air deleterious and unfit for survival. It is well known that burn pits are used to hide and destroy solid waste, particularly in military sites that carry toxic compounds, such as polycyclic aromatic hydrocarbons (PAHs), polychlorinated compounds, and particulates. A rodent model reported that exposure of adult mice to cadmium for 10 weeks changed gut-microbiota composition at the phylum and family levels. This same model also proposed that an increase in Bacteroidaceae boosts serum lipopolysaccharides (LPS). Moreover, it showed that the oral administration of B[a]P to experiment mice for 28 days resulted in moderate gastric inflammation and microbial-community shifts that included a decline in the level of anti-inflammatory taxa (e.g., Lactobacillus and Akkermansia), and an increase in the level of numerous inflammatory taxa [117-120].

\subsubsection{Effects of Noise on Gut Dysbiosis and Normal Microflora}

When rodents were exposed to acoustic stress, intestinal tight-junction protein expression was decreased, intestinal permeability was increased, GI motility was changed, inflammation and intestine-tissue damage increased, and gastric-ulcer induction was observed. However, a study demonstrated that exposure of aged mice to severe noise for $4 \mathrm{~h} /$ day up to 30 days changed cecal microbiota, which was characterized by an increase in Bacteroidetes/Firmicutes ratio, associated with decreased expression of tight-junction proteins in the colon and hippocampus, inflammation, and Alzheimer's-like cognitive impairments [121-129].

\subsubsection{Gut Dysbiosis Induces Neuroinflammation and Alzheimer's Disease Pathology}

The lipopolysaccharides are secreted by gut bacteria during dysbiosis that exaggerate Alzheimer's disease pathology, via the activation of amyloidogenic signaling pathways. Studies have suggested that bacterial-surface lipopolysaccharides bind with microglial receptors (TLR2, TLR4, and CD14) and activate the downstream NF- $\mathrm{kB}$ transcription factor. The activation of NF- $\mathrm{kB}$ producing proinflammatory cytokines that initiate neuroinflammatory responses. This neuroinflammatory response and reactive microglia activate various Alzheimer's pathways, such as beta-secretase 1 (BACE1; Figure 2) [130-136]. 


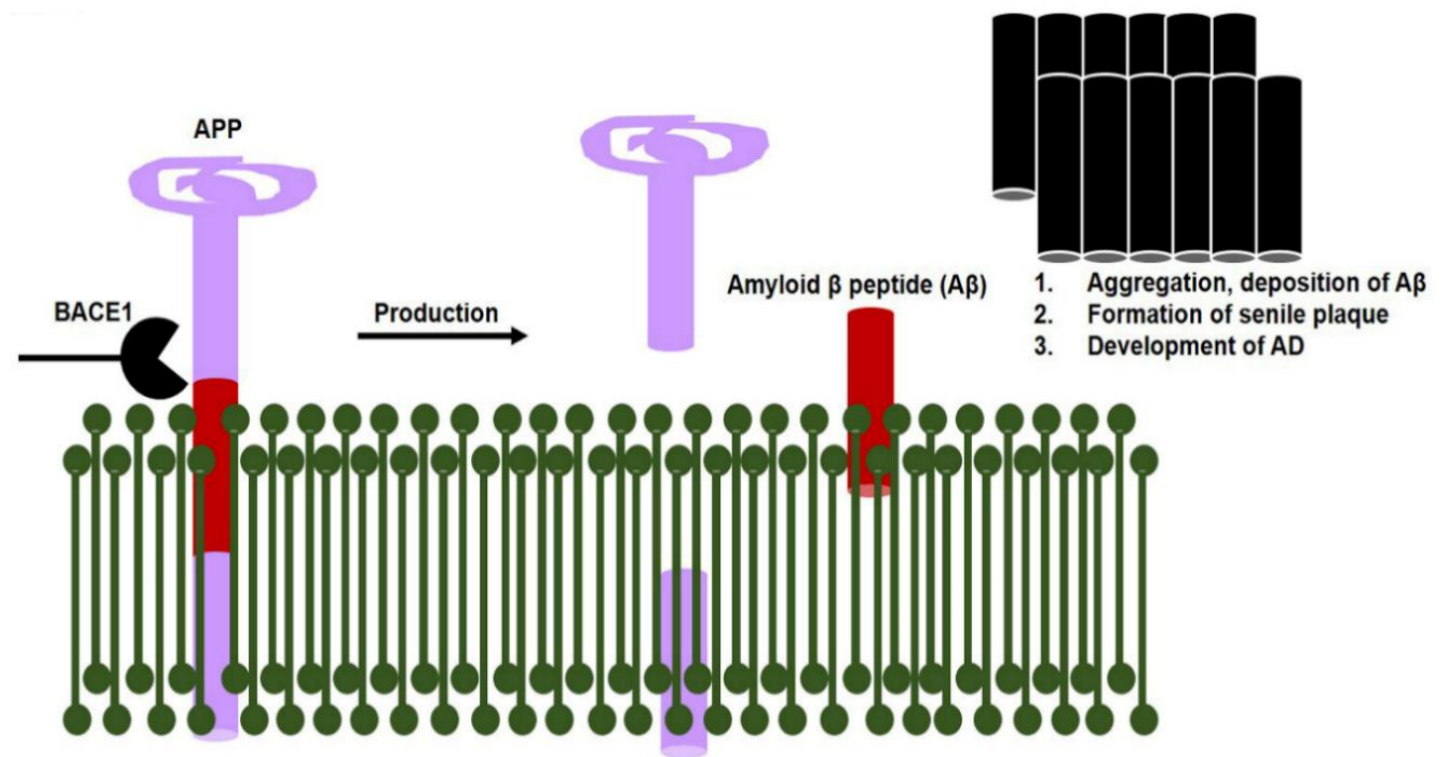

Figure 2. Increased beta-secretase 1 (BACE1) enzyme activity causes senile plaque formation. Increased BACE1 activity (when NF-kB transcription factor binds with its promoter region) causes abnormal APP cleavage that produces a burden of amyloid beta proteins. Consequences of amyloid beta plaques include Alzheimer's disease development.

However, a study revealed that lipopolysaccharides, endotoxins, and pathogens disrupt the gut and blood-brain barrier (BBB) tight junctions, and enter the brain, for example Salmonella, E. coli, and Citrobacter produce $A \beta$. In the brain, misfolding amyloid proteins may be triggered by an exposure to microbial communities. A prion-like mechanism is the same as the propagation and formation of A $\beta$ seeds [134,137-141]. One possibility is that epithelial cells of mucosa-associated lymphoid tissue collect and pass it to the parasympathetic neurons of the vagus nerve and enteric nervous system, from where they may gain entry to the CNS through retrograde axonal transport. Dysregulation of these molecules can lead to neurotoxicity and chronic inflammation.

1.3. Daily Use of Natural Dietary Anthocyanins Increases Beneficial-Microbe Population, Prevents Leaky Gut, and Inhibits Circulatory Inflammagen (LPS) and Proinflammatory Cytokines

Anthocyanins belong to flavonoids, are soluble in water, and are polyphenolic pigments that give color to food. There are some fruits and vegetables that are rich in anthocyanins, such as grapes, black plums, and blueberries, red and black rice, and black soybeans. The amount and composition of anthocyanins in different fruits and vegetables range from $0.1 \%$ to $1 \%$ (Figure 3 ). 

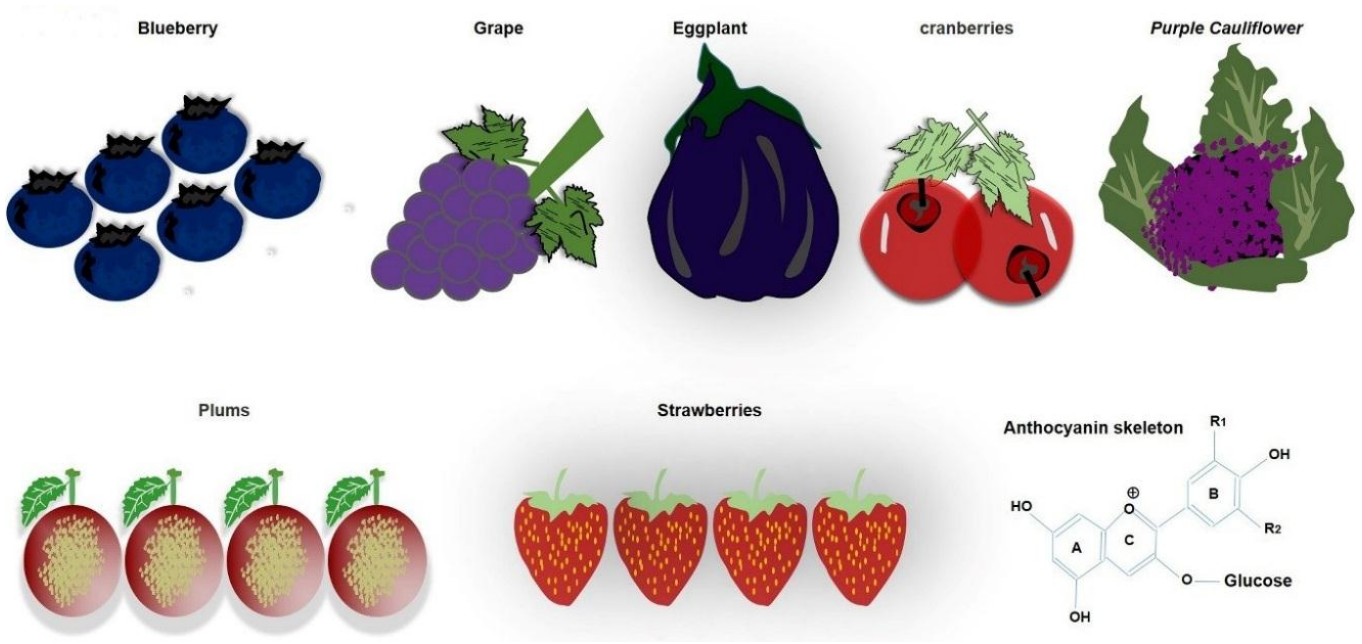

Figure 3. Natural dietary Anthocyanin sources. Various fruits and vegetables are rich sources of natural dietary anthocyanin.

Berries are a rich source of anthocyanins, so they may help in different functions of the body, as highlighted previously [142,143].

Furthermore, enzymolysis, oxidation, and climatic factors like light, temperature, and $\mathrm{pH}$ can change the level of anthocyanins. Acidic conditions are better for the stability of anthocyanins. In most cases though, it is degraded at high $\mathrm{pH}$. Anthocyanins are naturally present in plants as glycosides carrying glucose, galactose, arabinose, rhamnose, and xylose [144-153]. The unstable form of deglycosylated anthocyanins is called anthocyanidins, which are very rare in nature. The peculiar electron distribution and presence of flavylium ion are the reasons for anthocyanidin instability. On the basis of chemical structure, 700 anthocyanins and 27 aglycones have so far been recognized. The basic structure of anthocyanin comprises a C-6 (A ring)-C-3 (C ring)-C-6 (B ring) carbon skeleton with different numbers of sugars and hydroxyl groups, and varying degrees of methylation [144,146,153-157]. It was established that tight junctions provide a paracellular barrier that only allows select molecules into the intercellular space between epithelial cells (Figure 4).
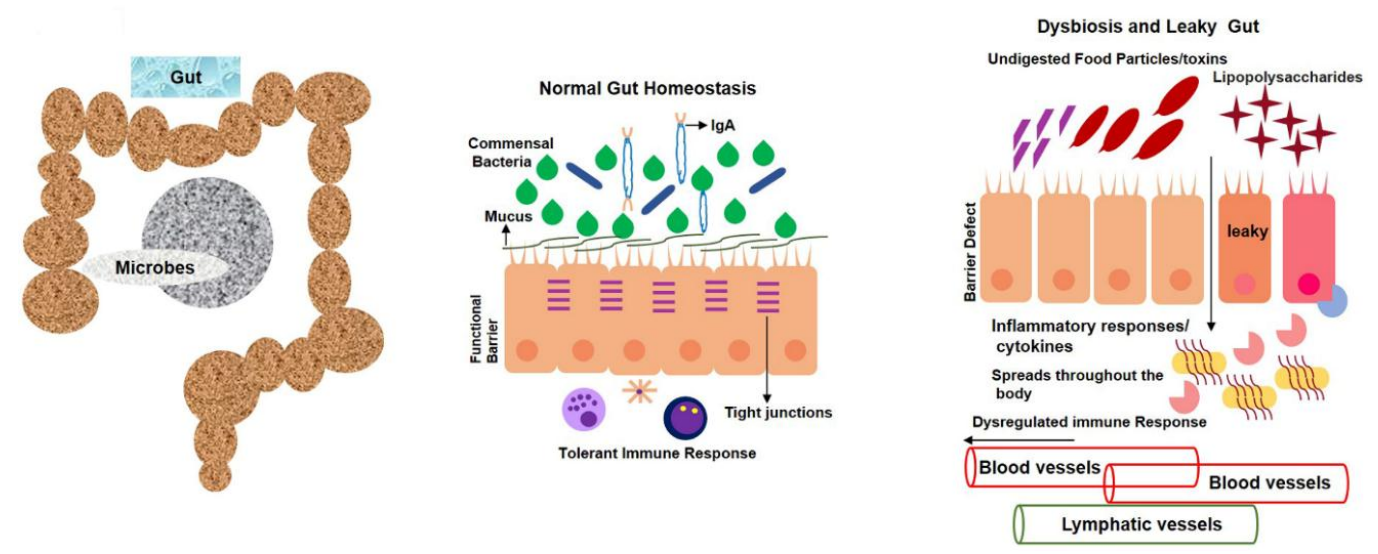

Figure 4. Leaky gut contributes to circulatory inflammagens and proinflammatory cytokines. Opportunistic bacteria produce various toxins and polysaccharides that, in turn, cause intestinal-wall inflammation that results in a leaky gut. Epithelial-cell inflammation also leads to loss of tight junctions that provide opportunities for undigested food particles, toxins, and inflammatory cytokines to enter bloodstream. Toxins and lipopolysaccharide (LPS)-containing blood later enter brain via blood-brain-barrier disruption. 
Cellular adhesion occurs because of occluding-regulated paracellular permeability. A classic TJ marker, ZO-1, works as an anchor and contributes to connecting occludin, claudin, and actin cytoskeletons to increase the epithelial barrier [158-169]. An in vivo study was carried out on rodents, where adult mice received $100 \mathrm{mg} / \mathrm{kg}$ black-rice extract per os (P.O.) for five days, in order to induce colitis, which indicated that mice that received black-rice extract had fewer histological lesions in their mucosa, as compared to dextran sodium sulfate-treated mice. It was suggested that anthocyanins prevent starch digestion by inhibiting the $\alpha$-amylase enzyme. When this undigested starch reaches the large intestine, it provides energy to probiotic bacteria, including Lactobacilli, Bifidobacteria, and Streptococci, which later on improves health conditions $[167,170-177]$.

\subsection{Anthocyanins Mitigate Gut Dysbiosis that Induces Neuroinflammation and Alzheimer's Pathology}

It was reported that LPS can enter the bloodstream via a damaged intestinal epithelium during an enteric-dysbiosis failure. The increase in the abundance of opportunistic pathogens could cause an increase in serum LPS levels. LPS further activates inflammatory pathways, including TLR4/NF-kB, which, in turn, leads to the release of proinflammatory cytokines, such as TNF- $\alpha, \mathrm{IL}-1 \beta$, and $\mathrm{CO}_{2}$, that then enter the bloodstream via a leaky gut (Figure 5) [178-180].

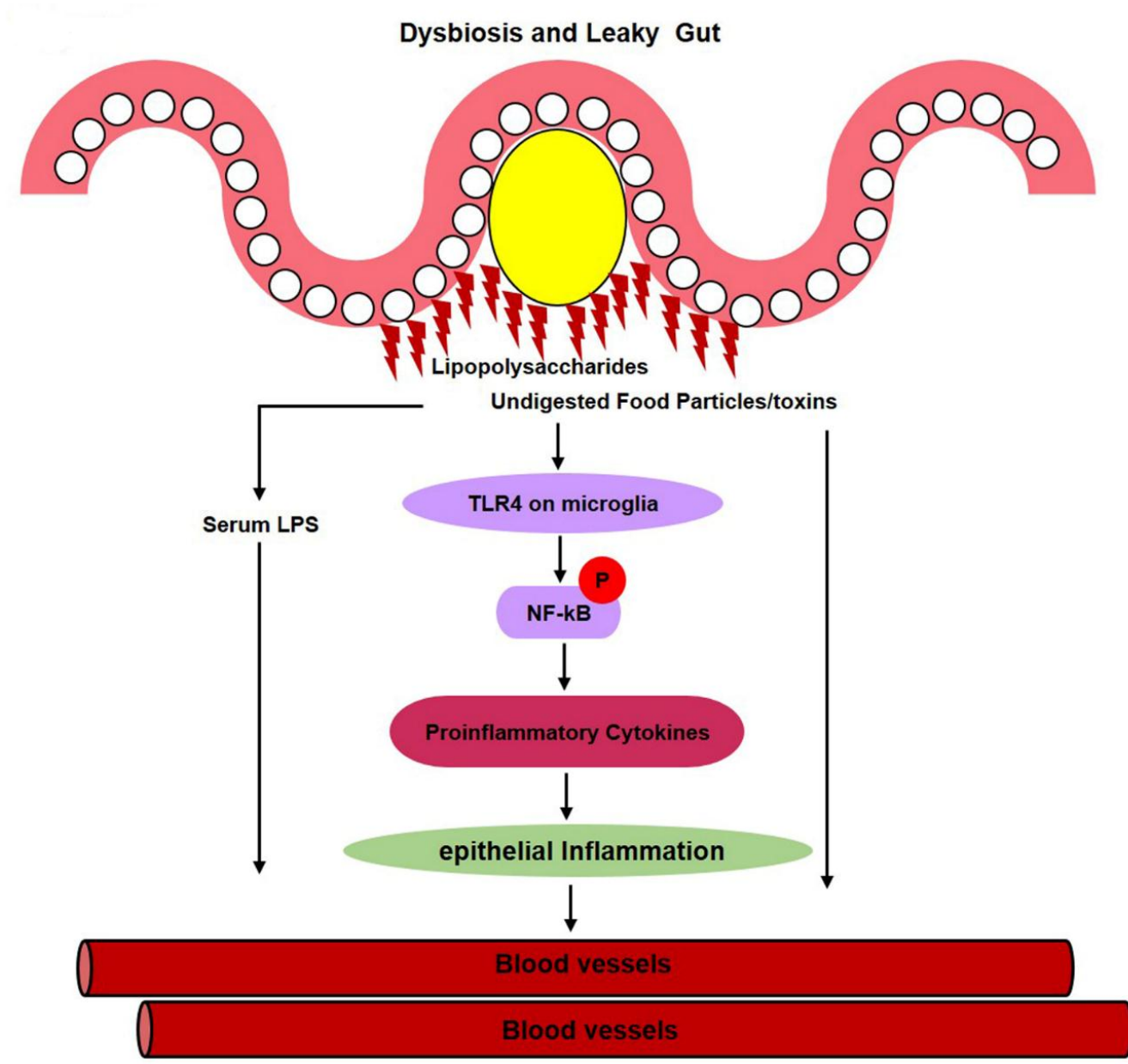

Figure 5. Gut dysbiosis causes epithelial inflammation. When harmful, particularly E. coli, Gram-negative bacteria secrete lipopolysaccharides that activate the TLR4 pathway and later on cause intestinal-wall and epithelial inflammation. This lipopolysaccharide not only activates the TLR4 signaling pathway, but also microglial and astrocyte cells in the gut, that then secrete proinflammatory cytokines. These proinflammatory cytokines later gain entry to the bloodstream via a leaky gut. This serum LPS then disrupts the blood-brain-barrier (BBB) and enters the brain, where it reactivates microglia, and various inflammatory and amyloid genic pathways. 
Previous studies reported that the abnormal cleavage of the amyloid beta protein by $\beta$-secretase results in amyloid beta plaque formation. Increased amyloid beta plaques accelerate neuronal cell death and Alzheimer's pathology [181-183]. Moreover, gut bacteria populating the microbiome were shown to produce amyloids and other immunogenic mediators that contribute to the modulation of signaling mechanisms implicated in neuroinflammation, brain $\mathrm{A} \beta$ deposition, and $\mathrm{AD}$ pathogenesis [184]. To explain how gut microbiota might contribute to AD pathogenesis, it was hypothesized that bacteria-derived amyloids leak from the gastrointestinal tract and accumulate at system and brain levels [185].

Here, we summarized the neuroinflammation-mediated amyloid beta burden and Alzheimer's pathology because, in dysbiosis, the opportunistic bacterial component (LPS) is prominently generated inside the gut, which later gains entry to the brain via the blood and causes a neuroinflammation-mediated amyloid beta burden (Figure 6) [186,187].

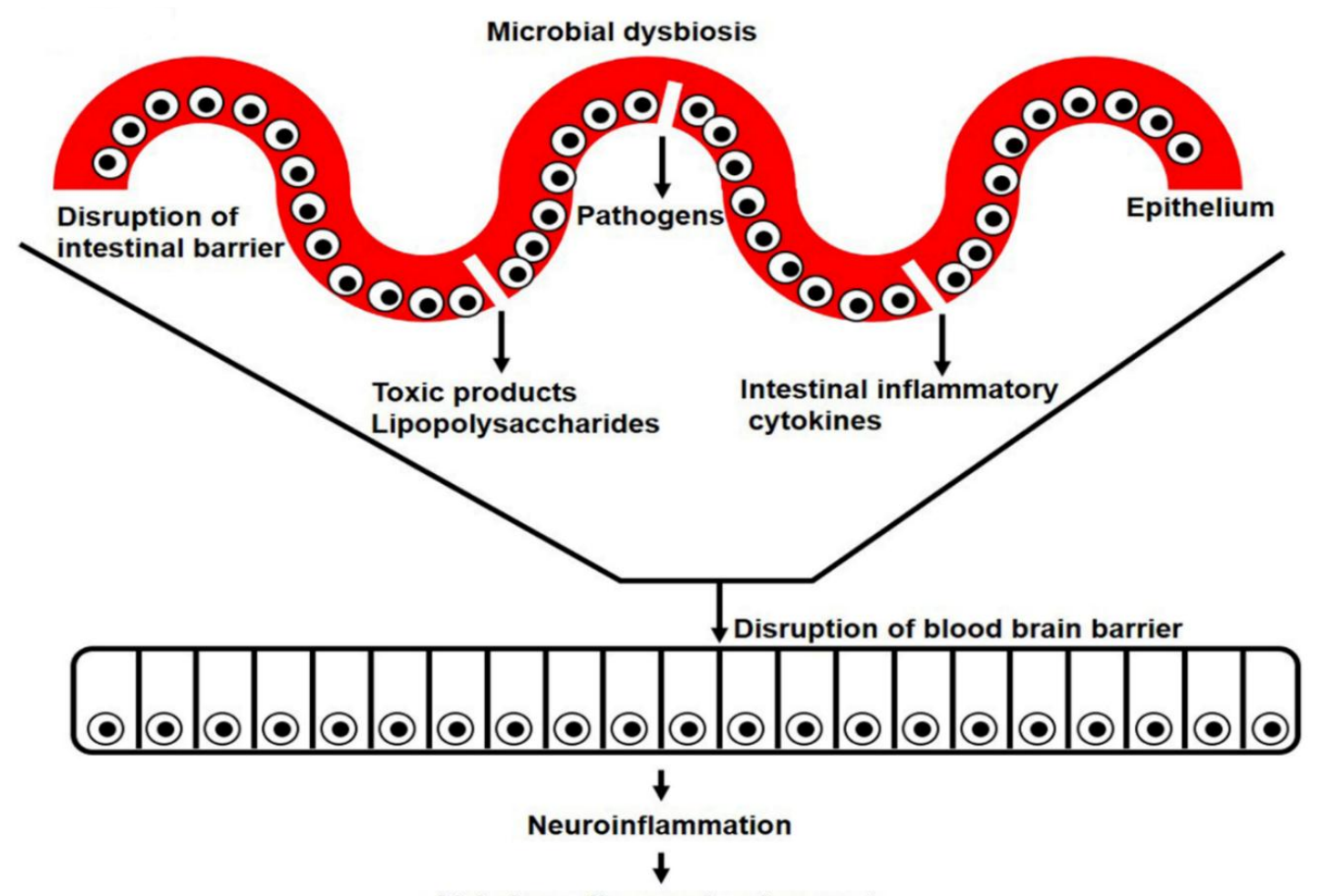

Alzheimer disease development

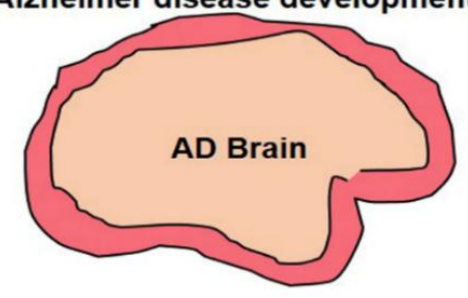

Figure 6. Gut-microbiota-secreted polysaccharides and other toxins cause neuroinflammation and Alzheimer's disease development. When circulatory lipopolysaccharides enter the brain, it activates inflammatory pathways and increases the number of reactive microglia. Increased inflammatory cytokines and NF- $\mathrm{kB}$ increase APP and amyloid beta protein cleavage and accumulation, and cause Alzheimer's disease development.

It has been reported that LPS is the ligand of the TLR4 receptor that exists on microglia cells. When LPS bind with TLR4, it activates the inflammatory cascade by translocating the downstream NF- $\kappa B$ to the nucleus. Once NF- $\kappa B$ phosphorylates, it binds with proinflammatory cytokine (TNF- $\alpha$, IL-1 $\beta$, and COX2) as a result, increases the neuroinflammation (Figure 7). 


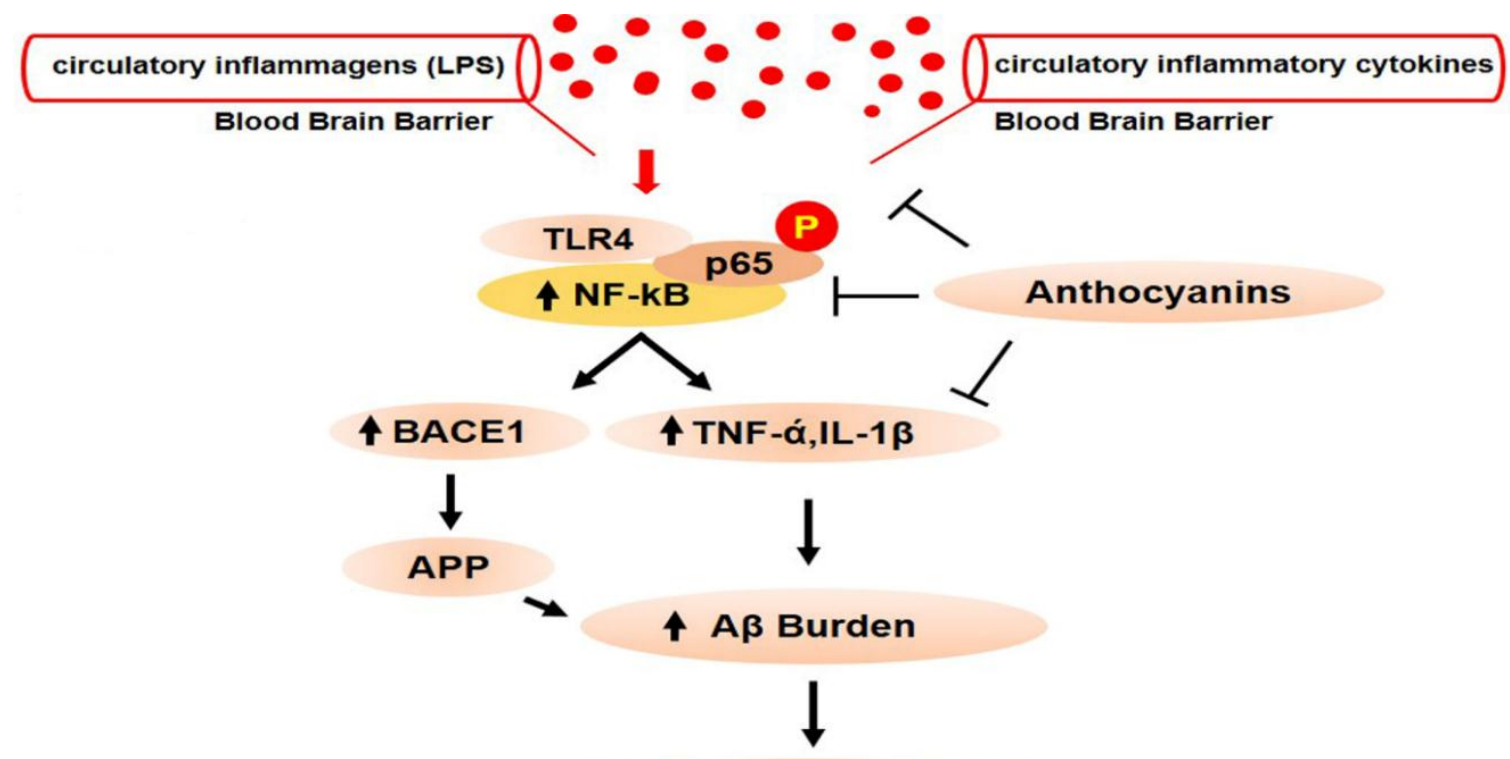

Amyloid Plaques

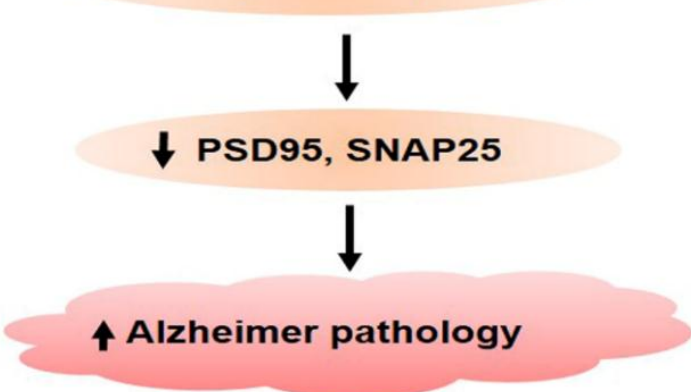

Figure 7. Anthocyanins prevent inflammatory and amyloid genic pathways in the central nervous system. When circulatory lipopolysaccharides and inflammatory cytokines gain entry to the brain, toll-like receptor 4 on microglia is activated, which subsequently leads to the activation of nuclear factor kappa B (NF-kB). After NF-kB phosphorylation and translocation to the nucleus, it goes on to bind with proinflammatory cytokine genes, that results in the production and release of proinflammatory cytokines. NF-KB also binds with the promoter region of BACE1 that produces $\beta$-secretase enzymes. Increased BACE1 activities later result in abnormal APP cleavage. Chronic deposition of amyloid beta proteins in the brain causes amyloid beta plaque formation and neuronal cell death. Amyloid beta plaques also deregulate pre- and postsynaptic proteins, which results in dementia and memory impairment.

Ali T and Khan, M.S. et al. recently reported that anthocyanins could significantly ameliorate the expression of proinflammatory cytokines and ROS/JNK, thus preventing neuroinflammation and Alzheimer's pathology [188-198]. Moreover, a study has shown the rescuing effects of anthocyanin against Alzheimer's disease pathology (APP, BACE-1, A $\beta$, and P-tau) and synapsis-related functions in A $\beta 1-42$-injected mice [199]. The effects of anthocyanin against gut-dysbiosis-induced neuroinflammation are in accordance with previously conducted studies, showing that nutrients have a significant effect against microbiota-induced neurocognitive disorders [200].

\section{Conclusions and Future Perspectives}

In our study, we focused on gut dysbiosis that induces systemic toxins, inflammagen-mediated neuroinflammation, and Alzheimer's pathology. We summarized that gut dysbiosis not only induces gastrointestinal disorder, particularly epithelial inflammation, tight-junction disruption, and leaky gut, 
but also contaminates the circulatory blood that results in BBB disruption, neuroinflammation-mediated Alzheimer's pathology, and memory dysfunction (Figure 8).

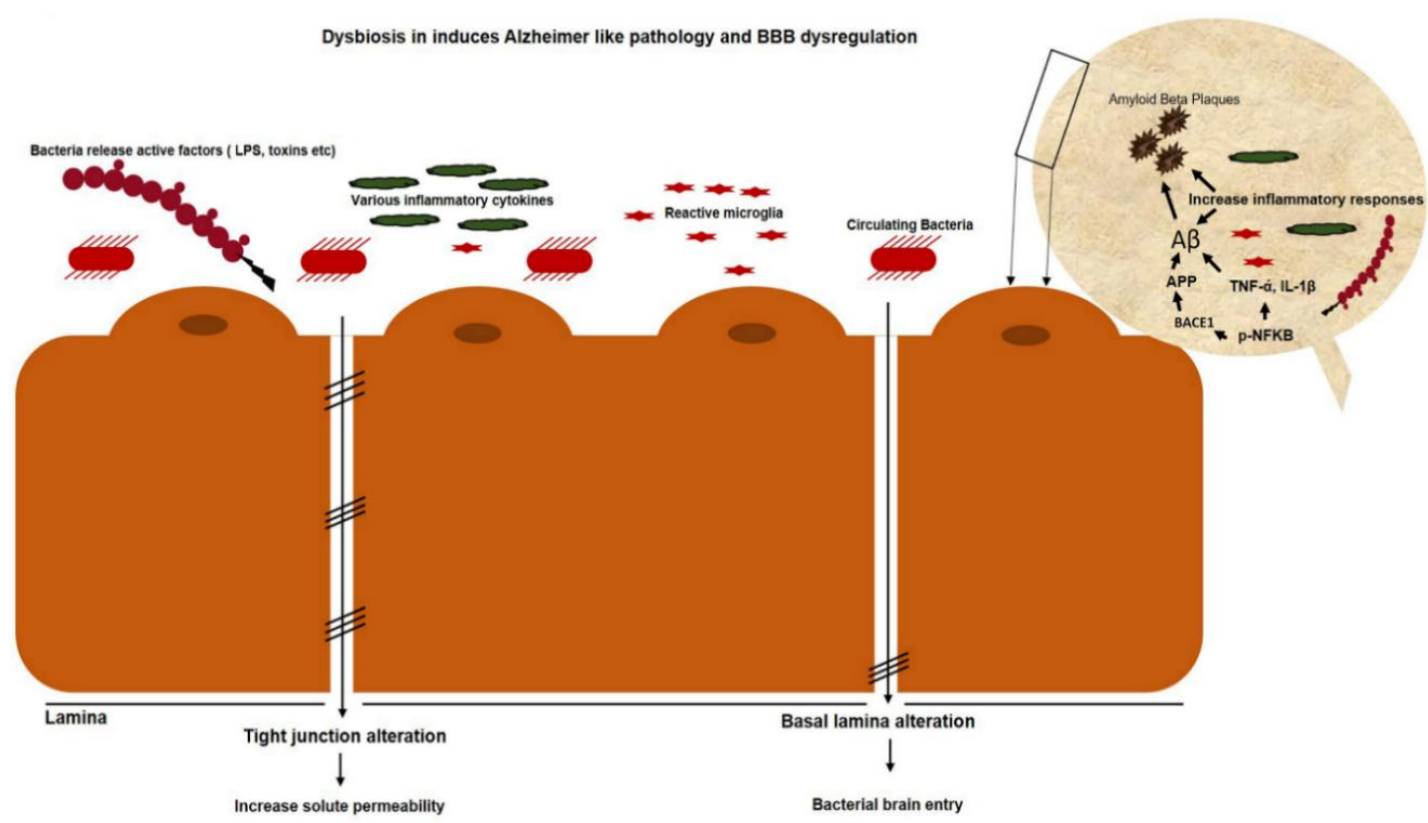

Figure 8. Circulatory toxins and lipopolysaccharides cause blood-brain barrier (BBB) disruption. Circulatory-microbe-secreted toxins, lipopolysaccharides, pathogens, and proinflammatory cytokines disrupt the blood-brain barrier and enter the brain, which activates various apoptotic, inflammatory, and amyloid genic pathways.

There are a number of signaling pathways that are involved in systemic inflammagen-mediated neuroinflammation and Alzheimer's pathology. However, we focused on the TLR4/NF-kB, ROS/JNK, and NF-kB/BACE1 pathways, and proposed that targeting these pathways by natural dietary polyflavonoid anthocyanins not only abrogates gut-dysbiosis-induced inflammagen (LPS, proinflammatory cytokines, toxic amines)-mediated neuroinflammation and Alzheimer's pathology, but also provides opportunities for clinical and preclinical studies in the future.

Author Contributions: M.S.K. \& M.I. are the equal contributors to this article, who wrote reviewed the manuscript. J.S.P. and T.J.P., are co-authors who critically reviewed the manuscript. M.O.K. is a corresponding author who reviewed, approved the manuscript and holds all the responsibilities related to this manuscript. All authors have read and agreed to the published version of the manuscript.

Acknowledgments: This research was supported by the Brain Research Program through the National Research Foundation of Korea (NRF) funded by the Ministry of Science, ICT (2016M3C7A1904391).

Conflicts of Interest: The authors declare no conflict of interest.

Consent for publication: Not applicable.

\section{References}

1. Cani, P.D. Human gut microbiome: Hopes, threats and promises. Gut 2018, 67, 1716-1725. [CrossRef] [PubMed]

2. Clemente, J.C.; Ursell, L.K.; Parfrey, L.W.; Knight, R. The impact of the gut microbiota on human health: An integrative view. Cell 2012, 148, 1258-1270. [CrossRef]

3. Jandhyala, S.M.; Talukdar, R.; Subramanyam, C.; Vuyyuru, H.; Sasikala, M.; Nageshwar Reddy, D. Role of the normal gut microbiota. World J. Gastroenterol. 2015, 21, 8787-8803. [CrossRef]

4. Von Martels, J.Z.H.; Sadaghian Sadabad, M.; Bourgonje, A.R.; Blokzijl, T.; Dijkstra, G.; Faber, K.N.; Harmsen, H.J.M. The role of gut microbiota in health and disease: In vitro modeling of host-microbe interactions at the aerobe-anaerobe interphase of the human gut. Anaerobe 2017, 44, 3-12. [CrossRef] 
5. Rajilic-Stojanovic, M. Function of the microbiota. Best Pr. Res. Clin. Gastroenterol. 2013, 27, 5-16. [CrossRef]

6. Musso, G.; Gambino, R.; Cassader, M. Obesity, diabetes, and gut microbiota: The hygiene hypothesis expanded? Diabetes Care 2010, 33, 2277-2284. [CrossRef]

7. Louis, P.; Hold, G.L.; Flint, H.J. The gut microbiota, bacterial metabolites and colorectal cancer. Nat. Rev. Microbiol. 2014, 12, 661-672. [CrossRef]

8. Correa-Oliveira, R.; Fachi, J.L.; Vieira, A.; Sato, F.T.; Vinolo, M.A. Regulation of immune cell function by short-chain fatty acids. Clin. Transl. Immunol. 2016, 5, e73. [CrossRef] [PubMed]

9. Macfarlane, S.; Macfarlane, G.T. Regulation of short-chain fatty acid production. Proc. Nutr. Soc. 2003, 62, 67-72. [CrossRef] [PubMed]

10. Morrison, D.J.; Preston, T. Formation of short chain fatty acids by the gut microbiota and their impact on human metabolism. Gut Microbes 2016, 7, 189-200. [CrossRef] [PubMed]

11. Louis, P.; Flint, H.J. Formation of propionate and butyrate by the human colonic microbiota. Environ. Microbiol. 2017, 19, 29-41. [CrossRef] [PubMed]

12. Derrien, M.; Vaughan, E.E.; Plugge, C.M.; de Vos, W.M. Akkermansia muciniphila gen. nov., sp. nov., a human intestinal mucin-degrading bacterium. Int. J. Syst. Evol. Microbiol. 2004, 54, 1469-1476. [CrossRef] [PubMed]

13. Guarner, F.; Malagelada, J.R. Gut flora in health and disease. Lancet 2003, 361, 512-519. [CrossRef]

14. Lin, L.; Zhang, J. Role of intestinal microbiota and metabolites on gut homeostasis and human diseases. BMC Immunol. 2017, 18, 2. [CrossRef]

15. Donohoe, D.R.; Collins, L.B.; Wali, A.; Bigler, R.; Sun, W.; Bultman, S.J. The Warburg effect dictates the mechanism of butyrate-mediated histone acetylation and cell proliferation. Mol. Cell 2012, 48, 612-626. [CrossRef] [PubMed]

16. Chambers, E.S.; Morrison, D.J.; Frost, G. Control of appetite and energy intake by SCFA: What are the potential underlying mechanisms? Proc. Nutr. Soc. 2015, 74, 328-336. [CrossRef] [PubMed]

17. Pingitore, A.; Chambers, E.S.; Hill, T.; Maldonado, I.R.; Liu, B.; Bewick, G.; Morrison, D.J.; Preston, T.; Wallis, G.A.; Tedford, C.; et al. The diet-derived short chain fatty acid propionate improves beta-cell function in humans and stimulates insulin secretion from human islets in vitro. Diabetes Obes. Metab. 2017, 19, 257-265. [CrossRef]

18. Byrne, C.S.; Chambers, E.S.; Alhabeeb, H.; Chhina, N.; Morrison, D.J.; Preston, T.; Tedford, C.; Fitzpatrick, J.; Irani, C.; Busza, A.; et al. Increased colonic propionate reduces anticipatory reward responses in the human striatum to high-energy foods. Am. J. Clin. Nutr. 2016, 104, 5-14. [CrossRef]

19. Nagai, M.; Obata, Y.; Takahashi, D.; Hase, K. Fine-tuning of the mucosal barrier and metabolic systems using the diet-microbial metabolite axis. Int. Immunopharm. 2016, 37, 79-86. [CrossRef]

20. Mazmanian, S.K.; Liu, C.H.; Tzianabos, A.O.; Kasper, D.L. An immunomodulatory molecule of symbiotic bacteria directs maturation of the host immune system. Cell 2005, 122, 107-118. [CrossRef]

21. Hevia, A.; Delgado, S.; Sanchez, B.; Margolles, A. Molecular Players Involved in the Interaction Between Beneficial Bacteria and the Immune System. Front. Microbiol. 2015, 6, 1285. [CrossRef] [PubMed]

22. Everard, A.; Belzer, C.; Geurts, L.; Ouwerkerk, J.P.; Druart, C.; Bindels, L.B.; Guiot, Y.; Derrien, M.; Muccioli, G.G.; Delzenne, N.M.; et al. Cross-talk between Akkermansia muciniphila and intestinal epithelium controls diet-induced obesity. Proc. Natl. Acad. Sci. USA 2013, 110, 9066-9071. [CrossRef] [PubMed]

23. Zhao, S.; Liu, W.; Wang, J.; Shi, J.; Sun, Y.; Wang, W.; Ning, G.; Liu, R.; Hong, J. Akkermansia muciniphila improves metabolic profiles by reducing inflammation in chow diet-fed mice. J. Mol. Endocrinol. 2017, 58, 1-14. [CrossRef] [PubMed]

24. Candela, M.; Biagi, E.; Maccaferri, S.; Turroni, S.; Brigidi, P. Intestinal microbiota is a plastic factor responding to environmental changes. Trends Microbiol. 2012, 20, 385-391. [CrossRef]

25. Le Chatelier, E.; Nielsen, T.; Qin, J.; Prifti, E.; Hildebrand, F.; Falony, G.; Almeida, M.; Arumugam, M.; Batto, J.M.; Kennedy, S.; et al. Richness of human gut microbiome correlates with metabolic markers. Nature 2013, 500, 541-546. [CrossRef]

26. Wang, L.; Christophersen, C.T.; Sorich, M.J.; Gerber, J.P.; Angley, M.T.; Conlon, M.A. Low relative abundances of the mucolytic bacterium Akkermansia muciniphila and Bifidobacterium spp. in feces of children with autism. Appl. Environ. Microbiol. 2011, 77, 6718-6721. [CrossRef]

27. Derrien, M.; Belzer, C.; de Vos, W.M. Akkermansia muciniphila and its role in regulating host functions. Microb. Pathog. 2017, 106, 171-181. [CrossRef] 
28. Sokol, H.; Seksik, P.; Furet, J.P.; Firmesse, O.; Nion-Larmurier, I.; Beaugerie, L.; Cosnes, J.; Corthier, G.; Marteau, P.; Dore, J. Low counts of Faecalibacterium prausnitzii in colitis microbiota. Inflamm. Bowel. Dis. 2009, 15, 1183-1189. [CrossRef]

29. Lopez-Siles, M.; Duncan, S.H.; Garcia-Gil, L.J.; Martinez-Medina, M. Faecalibacterium prausnitzii: From microbiology to diagnostics and prognostics. ISME J. 2017, 11, 841-852. [CrossRef]

30. Liu, T.; Zhang, L.; Joo, D.; Sun, S.C. NF-kappaB signaling in inflammation. Signal Transduct Target $2017,2$. [CrossRef]

31. Lakhdari, O.; Tap, J.; Beguet-Crespel, F.; Le Roux, K.; de Wouters, T.; Cultrone, A.; Nepelska, M.; Lefevre, F.; Dore, J.; Blottiere, H.M. Identification of NF-kappaB modulation capabilities within human intestinal commensal bacteria. J. Biomed. Biotechnol. 2011, 2011, 282356. [CrossRef] [PubMed]

32. Erkosar, B.; Defaye, A.; Bozonnet, N.; Puthier, D.; Royet, J.; Leulier, F. Drosophila microbiota modulates host metabolic gene expression via IMD/NF-kappaB signaling. PLoS ONE 2014, 9, e94729. [CrossRef]

33. Yan, F.; Polk, D.B. Disruption of NF-kappaB signalling by ancient microbial molecules: Novel therapies of the future? Gut 2010, 59, 421-426. [CrossRef] [PubMed]

34. Quevrain, E.; Maubert, M.A.; Michon, C.; Chain, F.; Marquant, R.; Tailhades, J.; Miquel, S.; Carlier, L.; Bermudez-Humaran, L.G.; Pigneur, B.; et al. Identification of an anti-inflammatory protein from Faecalibacterium prausnitzii, a commensal bacterium deficient in Crohn's disease. Gut 2016, 65, 415-425. [CrossRef]

35. Baumler, A.J.; Sperandio, V. Interactions between the microbiota and pathogenic bacteria in the gut. Nature 2016, 535, 85-93. [CrossRef]

36. Ferreyra, J.A.; Wu, K.J.; Hryckowian, A.J.; Bouley, D.M.; Weimer, B.C.; Sonnenburg, J.L. Gut microbiota-produced succinate promotes C. difficile infection after antibiotic treatment or motility disturbance. Cell Host Microbe 2014, 16, 770-777. [CrossRef]

37. Ng, K.M.; Ferreyra, J.A.; Higginbottom, S.K.; Lynch, J.B.; Kashyap, P.C.; Gopinath, S.; Naidu, N.; Choudhury, B.; Weimer, B.C.; Monack, D.M.; et al. Microbiota-liberated host sugars facilitate post-antibiotic expansion of enteric pathogens. Nature 2013, 502, 96-99. [CrossRef]

38. Huang, Y.L.; Chassard, C.; Hausmann, M.; von Itzstein, M.; Hennet, T. Sialic acid catabolism drives intestinal inflammation and microbial dysbiosis in mice. Nat. Commun. 2015, 6, 8141. [CrossRef]

39. Desai, M.S.; Seekatz, A.M.; Koropatkin, N.M.; Kamada, N.; Hickey, C.A.; Wolter, M.; Pudlo, N.A.; Kitamoto, S.; Terrapon, N.; Muller, A.; et al. A Dietary Fiber-Deprived Gut Microbiota Degrades the Colonic Mucus Barrier and Enhances Pathogen Susceptibility. Cell 2016, 167, 1339-1353 e1321. [CrossRef]

40. Hooper, L.V.; Macpherson, A.J. Immune adaptations that maintain homeostasis with the intestinal microbiota. Nat. Rev. Immunol. 2010, 10, 159-169. [CrossRef]

41. Mathias, A.; Pais, B.; Favre, L.; Benyacoub, J.; Corthesy, B. Role of secretory IgA in the mucosal sensing of commensal bacteria. Gut Microbes 2014, 5, 688-695. [CrossRef] [PubMed]

42. Rios, D.; Wood, M.B.; Li, J.; Chassaing, B.; Gewirtz, A.T.; Williams, I.R. Antigen sampling by intestinal M cells is the principal pathway initiating mucosal IgA production to commensal enteric bacteria. Mucosal. Immunol. 2016, 9, 907-916. [CrossRef] [PubMed]

43. Rogier, E.W.; Frantz, A.L.; Bruno, M.E.; Kaetzel, C.S. Secretory IgA is Concentrated in the Outer Layer of Colonic Mucus along with Gut Bacteria. Pathogens 2014, 3, 390-403. [CrossRef] [PubMed]

44. Moos, W.H.; Faller, D.V.; Harpp, D.N.; Kanara, I.; Pernokas, J.; Powers, W.R.; Steliou, K. Microbiota and Neurological Disorders: A Gut Feeling. Biores. Open Access. 2016, 5, 137-145. [CrossRef]

45. Penders, J.; Thijs, C.; Vink, C.; Stelma, F.F.; Snijders, B.; Kummeling, I.; van den Brandt, P.A.; Stobberingh, E.E. Factors influencing the composition of the intestinal microbiota in early infancy. Pediatrics 2006, 118, 511-521. [CrossRef]

46. Tanaka, S.; Kobayashi, T.; Songjinda, P.; Tateyama, A.; Tsubouchi, M.; Kiyohara, C.; Shirakawa, T.; Sonomoto, K.; Nakayama, J. Influence of antibiotic exposure in the early postnatal period on the development of intestinal microbiota. FEMS Immunol. Med. Microbiol. 2009, 56, 80-87. [CrossRef]

47. Penders, J.; Vink, C.; Driessen, C.; London, N.; Thijs, C.; Stobberingh, E.E. Quantification of Bifidobacterium spp., Escherichia coli and Clostridium difficile in faecal samples of breast-fed and formula-fed infants by real-time PCR. FEMS Microbiol. Lett. 2005, 243, 141-147. [CrossRef] 
48. Turnbaugh, P.J.; Ridaura, V.K.; Faith, J.J.; Rey, F.E.; Knight, R.; Gordon, J.I. The effect of diet on the human gut microbiome: A metagenomic analysis in humanized gnotobiotic mice. Sci. Transl. Med. 2009, 1, 6 ra14. [CrossRef]

49. O'Mahony, S.M.; Marchesi, J.R.; Scully, P.; Codling, C.; Ceolho, A.M.; Quigley, E.M.; Cryan, J.F.; Dinan, T.G. Early life stress alters behavior, immunity, and microbiota in rats: Implications for irritable bowel syndrome and psychiatric illnesses. Biol. Psychiatry 2009, 65, 263-267. [CrossRef]

50. Schmidt, B.; Mulder, I.E.; Musk, C.C.; Aminov, R.I.; Lewis, M.; Stokes, C.R.; Bailey, M.; Prosser, J.I.; Gill, B.P.; Pluske, J.R.; et al. Establishment of normal gut microbiota is compromised under excessive hygiene conditions. PLOS ONE 2011, 6, e28284. [CrossRef]

51. Dominguez-Bello, M.G.; Costello, E.K.; Contreras, M.; Magris, M.; Hidalgo, G.; Fierer, N.; Knight, R. Delivery mode shapes the acquisition and structure of the initial microbiota across multiple body habitats in newborns. Proc. Natl. Acad. Sci. USA 2010, 107, 11971-11975. [CrossRef] [PubMed]

52. Salminen, S.; Gibson, G.R.; McCartney, A.L.; Isolauri, E. Influence of mode of delivery on gut microbiota composition in seven year old children. Gut 2004, 53, 1388-1389. [CrossRef] [PubMed]

53. Fallani, M.; Young, D.; Scott, J.; Norin, E.; Amarri, S.; Adam, R.; Aguilera, M.; Khanna, S.; Gil, A.; Edwards, C.A.; et al. Intestinal microbiota of 6-week-old infants across Europe: Geographic influence beyond delivery mode, breast-feeding, and antibiotics. J. Pediatr. Gastroenterol. Nutr. 2010, 51, 77-84. [CrossRef] [PubMed]

54. Zhang, C.; Zhang, M.; Wang, S.; Han, R.; Cao, Y.; Hua, W.; Mao, Y.; Zhang, X.; Pang, X.; Wei, C.; et al. Interactions between gut microbiota, host genetics and diet relevant to development of metabolic syndromes in mice. ISME J. 2010, 4, 232-241. [CrossRef]

55. Sekirov, I.; Russell, S.L.; Antunes, L.C.; Finlay, B.B. Gut microbiota in health and disease. Physiol. Rev. 2010, 90, 859-904. [CrossRef]

56. Hildebrandt, M.A.; Hoffmann, C.; Sherrill-Mix, S.A.; Keilbaugh, S.A.; Hamady, M.; Chen, Y.Y.; Knight, R.; Ahima, R.S.; Bushman, F.; Wu, G.D. High-fat diet determines the composition of the murine gut microbiome independently of obesity. Gastroenterology 2009, 137, 1716-1724. [CrossRef]

57. Wu, G.D.; Chen, J.; Hoffmann, C.; Bittinger, K.; Chen, Y.Y.; Keilbaugh, S.A.; Bewtra, M.; Knights, D.; Walters, W.A.; Knight, R.; et al. Linking long-term dietary patterns with gut microbial enterotypes. Science 2011, 334, 105-108. [CrossRef]

58. Simoes, C.D.; Maukonen, J.; Kaprio, J.; Rissanen, A.; Pietilainen, K.H.; Saarela, M. Habitual dietary intake is associated with stool microbiota composition in monozygotic twins. J. Nutr. 2013, 143, 417-423. [CrossRef]

59. Gerard, P. Metabolism of cholesterol and bile acids by the gut microbiota. Pathogens 2013, 3, 14-24. [CrossRef]

60. Blaut, M.; Klaus, S. Intestinal microbiota and obesity. Handb Exp. Pharm. 2012, 251-273. [CrossRef]

61. Shang, Y.; Khafipour, E.; Derakhshani, H.; Sarna, L.K.; Woo, C.W.; Siow, Y.L.; O, K. Short Term High Fat Diet Induces Obesity-Enhancing Changes in Mouse Gut Microbiota that Are Partially Reversed by Cessation of the High Fat Diet. Lipids 2017, 52, 499-511. [CrossRef] [PubMed]

62. Arias-Jayo, N.; Abecia, L.; Alonso-Saez, L.; Ramirez-Garcia, A.; Rodriguez, A.; Pardo, M.A. High-Fat Diet Consumption Induces Microbiota Dysbiosis and Intestinal Inflammation in Zebrafish. Microb. Ecol. 2018, 76, 1089-1101. [CrossRef] [PubMed]

63. Alhasson, F.; Das, S.; Seth, R.; Dattaroy, D.; Chandrashekaran, V.; Ryan, C.N.; Chan, L.S.; Testerman, T.; Burch, J.; Hofseth, L.J.; et al. Altered gut microbiome in a mouse model of Gulf War Illness causes neuroinflammation and intestinal injury via leaky gut and TLR4 activation. PLoS ONE 2017, 12, e0172914. [CrossRef] [PubMed]

64. Anitha, M.; Reichardt, F.; Tabatabavakili, S.; Nezami, B.G.; Chassaing, B.; Mwangi, S.; Vijay-Kumar, M.; Gewirtz, A.; Srinivasan, S. Intestinal dysbiosis contributes to the delayed gastrointestinal transit in high-fat diet fed mice. Cell Mol. Gastroenterol. Hepatol. 2016, 2, 328-339. [CrossRef]

65. He, Q.; Wang, L.; Wang, F.; Wang, C.; Tang, C.; Li, Q.; Li, J.; Zhao, Q. Microbial fingerprinting detects intestinal microbiota dysbiosis in Zebrafish models with chemically-induced enterocolitis. BMC Microbiol. 2013, 13, 289. [CrossRef]

66. Fawley, J.; Koehler, S.; Cabrera, S.; Lam, V.; Fredrich, K.; Hessner, M.; Salzman, N.; Gourlay, D. Intestinal alkaline phosphatase deficiency leads to dysbiosis and bacterial translocation in the newborn intestine. J. Surg. Res. 2017, 218, 35-42. [CrossRef] 
67. Porter, C.K.; Thura, N.; Riddle, M.S. Quantifying the incidence and burden of postinfectious enteric sequelae. Mil. Med. 2013, 178, 452-469. [CrossRef]

68. Phua, L.C.; Wilder-Smith, C.H.; Tan, Y.M.; Gopalakrishnan, T.; Wong, R.K.; Li, X.; Kan, M.E.; Lu, J.; Keshavarzian, A.; Chan, E.C. Gastrointestinal Symptoms and Altered Intestinal Permeability Induced by Combat Training Are Associated with Distinct Metabotypic Changes. J. Proteome. Res. 2015, 14, 4734-4742. [CrossRef]

69. Mackos, A.R.; Maltz, R.; Bailey, M.T. The role of the commensal microbiota in adaptive and maladaptive stressor-induced immunomodulation. Horm. Behav. 2017, 88, 70-78. [CrossRef]

70. Li, X.; Kan, E.M.; Lu, J.; Cao, Y.; Wong, R.K.; Keshavarzian, A.; Wilder-Smith, C.H. Combat-training increases intestinal permeability, immune activation and gastrointestinal symptoms in soldiers. Aliment. Pharm. 2013, 37, 799-809. [CrossRef]

71. Karl, J.P.; Margolis, L.M.; Murphy, N.E.; Carrigan, C.T.; Castellani, J.W.; Madslien, E.H.; Teien, H.K.; Martini, S.; Montain, S.J.; Pasiakos, S.M. Military training elicits marked increases in plasma metabolomic signatures of energy metabolism, lipolysis, fatty acid oxidation, and ketogenesis. Physiol. Rep. 2017, 5. [CrossRef]

72. Karl, J.P.; Margolis, L.M.; Madslien, E.H.; Murphy, N.E.; Castellani, J.W.; Gundersen, Y.; Hoke, A.V.; Levangie, M.W.; Kumar, R.; Chakraborty, N.; et al. Changes in intestinal microbiota composition and metabolism coincide with increased intestinal permeability in young adults under prolonged physiological stress. Am. J. Physiol. Gastrointest. Liver Physiol. 2017, 312, G559-G571. [CrossRef]

73. Jacobs, J.M.; Cameron, K.L.; Bojescul, J.A. Lower extremity stress fractures in the military. Clin. Sports Med. 2014, 33, 591-613. [CrossRef]

74. Glaser, R.; Kiecolt-Glaser, J.K. Stress-induced immune dysfunction: Implications for health. Nat. Rev. Immunol. 2005, 5, 243-251. [CrossRef]

75. Russell, A.; Deuster, P.A. Human Performance Optimization and Precision Performance: The Future of Special Operations Human Performance Efforts. J. Spec. Oper. Med. 2017, 17, 80-89.

76. Henning, P.C.; Park, B.S.; Kim, J.S. Physiological decrements during sustained military operational stress. Mil. Med. 2011, 176, 991-997. [CrossRef]

77. Glaven, S.; Racicot, K.; Leary, D.H.; Karl, J.P.; Arcidiacono, S.; Dancy, B.C.R.; Chrisey, L.A.; Soares, J.W. The Current and Future State of Department of Defense (DoD) Microbiome Research: A Summary of the Inaugural DoD Tri-Service Microbiome Consortium Informational Meeting. mSystems 2018, 3. [CrossRef] [PubMed]

78. Clark, A.; Mach, N. Exercise-induced stress behavior, gut-microbiota-brain axis and diet: A systematic review for athletes. J. Int. Soc. Sports Nutr. 2016, 13, 43. [CrossRef] [PubMed]

79. Alexander, D.A.; Klein, S. First responders after disasters: A review of stress reactions, at-risk, vulnerability, and resilience factors. Prehosp. Disaster Med. 2009, 24, 87-94. [CrossRef] [PubMed]

80. Segerstrom, S.C.; Miller, G.E. Psychological stress and the human immune system: A meta-analytic study of 30 years of inquiry. Psychol. Bull. 2004, 130, 601-630. [CrossRef] [PubMed]

81. Mawdsley, J.E.; Rampton, D.S. Psychological stress in IBD: New insights into pathogenic and therapeutic implications. Gut 2005, 54, 1481-1491. [CrossRef] [PubMed]

82. Konturek, P.C.; Brzozowski, T.; Konturek, S.J. Stress and the gut: Pathophysiology, clinical consequences, diagnostic approach and treatment options. J. Physiol. Pharm. 2011, 62, 591-599.

83. Hammamieh, R.; Chakraborty, N.; De Lima, T.C.; Meyerhoff, J.; Gautam, A.; Muhie, S.; D'Arpa, P.; Lumley, L.; Carroll, E.; Jett, M. Murine model of repeated exposures to conspecific trained aggressors simulates features of post-traumatic stress disorder. Behav. Brain Res. 2012, 235, 55-66. [CrossRef] [PubMed]

84. Gautam, A.; D’Arpa, P.; Donohue, D.E.; Muhie, S.; Chakraborty, N.; Luke, B.T.; Grapov, D.; Carroll, E.E.; Meyerhoff, J.L.; Hammamieh, R.; et al. Acute and chronic plasma metabolomic and liver transcriptomic stress effects in a mouse model with features of post-traumatic stress disorder. PLoS ONE 2015, 10, e0117092. [CrossRef] [PubMed]

85. Gareau, M.G.; Silva, M.A.; Perdue, M.H. Pathophysiological mechanisms of stress-induced intestinal damage. Curr. Mol. Med. 2008, 8, 274-281. [CrossRef]

86. Kelly, J.R.; Kennedy, P.J.; Cryan, J.F.; Dinan, T.G.; Clarke, G.; Hyland, N.P. Breaking down the barriers: The gut microbiome, intestinal permeability and stress-related psychiatric disorders. Front. Cell Neurosci. 2015, 9, 392. [CrossRef] [PubMed] 
87. Kato-Kataoka, A.; Nishida, K.; Takada, M.; Kawai, M.; Kikuchi-Hayakawa, H.; Suda, K.; Ishikawa, H.; Gondo, Y.; Shimizu, K.; Matsuki, T.; et al. Fermented Milk Containing Lactobacillus casei Strain Shirota Preserves the Diversity of the Gut Microbiota and Relieves Abdominal Dysfunction in Healthy Medical Students Exposed to Academic Stress. Appl. Environ. Microbiol. 2016, 82, 3649-3658. [CrossRef] [PubMed]

88. Forsythe, P.; Kunze, W.; Bienenstock, J. Moody microbes or fecal phrenology: What do we know about the microbiota-gut-brain axis? BMC Med. 2016, 14, 58. [CrossRef]

89. Cryan, J.F.; Dinan, T.G. Mind-altering microorganisms: The impact of the gut microbiota on brain and behaviour. Nat. Rev. Neurosci. 2012, 13, 701-712. [CrossRef]

90. Sket, R.; Treichel, N.; Kublik, S.; Debevec, T.; Eiken, O.; Mekjavic, I.; Schloter, M.; Vital, M.; Chandler, J.; Tiedje, J.M.; et al. Hypoxia and inactivity related physiological changes precede or take place in absence of significant rearrangements in bacterial community structure: The PlanHab randomized trial pilot study. PLoS ONE 2017, 12, e0188556. [CrossRef]

91. Sket, R.; Treichel, N.; Debevec, T.; Eiken, O.; Mekjavic, I.; Schloter, M.; Vital, M.; Chandler, J.; Tiedje, J.M.; Murovec, B.; et al. Hypoxia and Inactivity Related Physiological Changes (Constipation, Inflammation) Are Not Reflected at the Level of Gut Metabolites and Butyrate Producing Microbial Community: The PlanHab Study. Front. Physiol. 2017, 8, 250. [CrossRef] [PubMed]

92. Sket, R.; Debevec, T.; Kublik, S.; Schloter, M.; Schoeller, A.; Murovec, B.; Vogel Mikus, K.; Makuc, D.; Pecnik, K.; Plavec, J.; et al. Intestinal Metagenomes and Metabolomes in Healthy Young Males: Inactivity and Hypoxia Generated Negative Physiological Symptoms Precede Microbial Dysbiosis. Front. Physiol. 2018, 9, 198. [CrossRef] [PubMed]

93. Millet, G.P.; Faiss, R.; Pialoux, V. Point: Hypobaric hypoxia induces different physiological responses from normobaric hypoxia. J. Appl. Physiol. 2012, 112, 1783-1784. [CrossRef] [PubMed]

94. Kleessen, B.; Schroedl, W.; Stueck, M.; Richter, A.; Rieck, O.; Krueger, M. Microbial and immunological responses relative to high-altitude exposure in mountaineers. Med. Sci. Sports Exerc. 2005, 37, 1313-1318. [CrossRef]

95. Adak, A.; Maity, C.; Ghosh, K.; Pati, B.R.; Mondal, K.C. Dynamics of predominant microbiota in the human gastrointestinal tract and change in luminal enzymes and immunoglobulin profile during high-altitude adaptation. Folia.Microbiol. (Praha) 2013, 58, 523-528. [CrossRef]

96. Wilson, T.E.; Sauder, C.L.; Kearney, M.L.; Kuipers, N.T.; Leuenberger, U.A.; Monahan, K.D.; Ray, C.A. Skin-surface cooling elicits peripheral and visceral vasoconstriction in humans. J. Appl. Physiol. 2007, 103, 1257-1262. [CrossRef]

97. Senay, E.C.; Levine, R.J. Synergism between cold and restraint for rapid production of stress ulcers in rats. Proc. Soc. Exp. Biol. Med. 1967, 124, 1221-1223. [CrossRef]

98. Saunders, P.R.; Kosecka, U.; McKay, D.M.; Perdue, M.H. Acute stressors stimulate ion secretion and increase epithelial permeability in rat intestine. Am. J. Physiol. 1994, 267, G794-G799. [CrossRef]

99. Coskun, T.; Yegen, B.C.; Alican, I.; Peker, O.; Kurtel, H. Cold restraint stress-induced gastric mucosal dysfunction. Role of nitric oxide. Dig. Dis. Sci. 1996, 41, 956-963. [CrossRef]

100. Castellani, J.W.; Young, A.J. Human physiological responses to cold exposure: Acute responses and acclimatization to prolonged exposure. Auton. Neurosci. 2016, 196, 63-74. [CrossRef]

101. Zietak, M.; Kovatcheva-Datchary, P.; Markiewicz, L.H.; Stahlman, M.; Kozak, L.P.; Backhed, F. Altered Microbiota Contributes to Reduced Diet-Induced Obesity upon Cold Exposure. Cell Metab. 2016, 23, 1216-1223. [CrossRef] [PubMed]

102. Kokou, F.; Sasson, G.; Nitzan, T.; Doron-Faigenboim, A.; Harpaz, S.; Cnaani, A.; Mizrahi, I. Host genetic selection for cold tolerance shapes microbiome composition and modulates its response to temperature. Elife 2018, 7. [CrossRef] [PubMed]

103. Zhang, X.Y.; Sukhchuluun, G.; Bo, T.B.; Chi, Q.S.; Yang, J.J.; Chen, B.; Zhang, L.; Wang, D.H. Huddling remodels gut microbiota to reduce energy requirements in a small mammal species during cold exposure. Microbiome 2018, 6, 103. [CrossRef]

104. Sanders, J.W.; Putnam, S.D.; Riddle, M.S.; Tribble, D.R.; Jobanputra, N.K.; Jones, J.J.; Scott, D.A.; Frenck, R.W. The epidemiology of self-reported diarrhea in operations Iraqi freedom and enduring freedom. Diagn. Microbiol. Infect. Dis. 2004, 50, 89-93. [CrossRef] [PubMed]

105. Riddle, M.S.; Tribble, D.R.; Putnam, S.D.; Mostafa, M.; Brown, T.R.; Letizia, A.; Armstrong, A.W.; Sanders, J.W. Past trends and current status of self-reported incidence and impact of disease and nonbattle injury in military 
operations in Southwest Asia and the Middle East. Am. J. Public Health 2008, 98, 2199-2206. [CrossRef] [PubMed]

106. Riddle, M.S.; Martin, G.J.; Murray, C.K.; Burgess, T.H.; Connor, P.; Mancuso, J.D.; Schnaubelt, E.R.; Ballard, T.P.; Fraser, J.; Tribble, D.R. Management of Acute Diarrheal Illness During Deployment: A Deployment Health Guideline and Expert Panel Report. Mil. Med. 2017, 182, 34-52. [CrossRef] [PubMed]

107. Riddle, M.S.; DuPont, H.L.; Connor, B.A. ACG Clinical Guideline: Diagnosis, Treatment, and Prevention of Acute Diarrheal Infections in Adults. Am. J. Gastroenterol. 2016, 111, 602-622. [CrossRef] [PubMed]

108. Porter, C.K.; Olson, S.; Hall, A.; Riddle, M.S. Travelers' Diarrhea: An Update on the Incidence, Etiology, and Risk in Military Deployments and Similar Travel Populations. Mil. Med. 2017, 182, 4-10. [CrossRef]

109. Navaneethan, U.; Giannella, R.A. Mechanisms of infectious diarrhea. Nat. Clin. Pr. Gastroenterol. Hepatol. 2008, 5, 637-647. [CrossRef]

110. Ferrer, M.; Mendez-Garcia, C.; Rojo, D.; Barbas, C.; Moya, A. Antibiotic use and microbiome function. Biochem. Pharm. 2017, 134, 114-126. [CrossRef]

111. Zaura, E.; Brandt, B.W.; Teixeira de Mattos, M.J.; Buijs, M.J.; Caspers, M.P.; Rashid, M.U.; Weintraub, A.; Nord, C.E.; Savell, A.; Hu, Y.; et al. Same Exposure but Two Radically Different Responses to Antibiotics: Resilience of the Salivary Microbiome versus Long-Term Microbial Shifts in Feces. mBio 2015, 6, e01693-15. [CrossRef] [PubMed]

112. Ladirat, S.E.; Schoterman, M.H.; Rahaoui, H.; Mars, M.; Schuren, F.H.; Gruppen, H.; Nauta, A.; Schols, H.A. Exploring the effects of galacto-oligosaccharides on the gut microbiota of healthy adults receiving amoxicillin treatment. Br. J. Nutr. 2014, 112, 536-546. [CrossRef] [PubMed]

113. Jernberg, C.; Lofmark, S.; Edlund, C.; Jansson, J.K. Long-term ecological impacts of antibiotic administration on the human intestinal microbiota. ISME J. 2007, 1, 56-66. [CrossRef] [PubMed]

114. Jakobsson, H.E.; Jernberg, C.; Andersson, A.F.; Sjolund-Karlsson, M.; Jansson, J.K.; Engstrand, L. Short-term antibiotic treatment has differing long-term impacts on the human throat and gut microbiome. PLoS ONE 2010, 5, e9836. [CrossRef] [PubMed]

115. Dethlefsen, L.; Relman, D.A. Incomplete recovery and individualized responses of the human distal gut microbiota to repeated antibiotic perturbation. Proc. Natl. Acad. Sci. USA 2011, 108 (Suppl. 1), 4554-4561. [CrossRef]

116. Modi, S.R.; Collins, J.J.; Relman, D.A. Antibiotics and the gut microbiota. J. Clin. Investig. 2014, 124, 4212-4218. [CrossRef]

117. Ribiere, C.; Peyret, P.; Parisot, N.; Darcha, C.; Dechelotte, P.J.; Barnich, N.; Peyretaillade, E.; Boucher, D. Oral exposure to environmental pollutant benzo [a] pyrene impacts the intestinal epithelium and induces gut microbial shifts in murine model. Sci. Rep. 2016, 6, 31027. [CrossRef]

118. Joly, C.; Gay-Queheillard, J.; Leke, A.; Chardon, K.; Delanaud, S.; Bach, V.; Khorsi-Cauet, H. Impact of chronic exposure to low doses of chlorpyrifos on the intestinal microbiota in the Simulator of the Human Intestinal Microbial Ecosystem (SHIME) and in the rat. Environ. Sci. Pollut. Res. Int. 2013, 20, 2726-2734. [CrossRef]

119. Huderson, A.C.; Myers, J.N.; Niaz, M.S.; Washington, M.K.; Ramesh, A. Chemoprevention of benzo(a)pyrene-induced colon polyps in ApcMin mice by resveratrol. J. Nutr. Biochem. 2013, 24, 713-724. [CrossRef]

120. Defois, C.; Ratel, J.; Denis, S.; Batut, B.; Beugnot, R.; Peyretaillade, E.; Engel, E.; Peyret, P. Environmental Pollutant Benzo [a] Pyrene Impacts the Volatile Metabolome and Transcriptome of the Human Gut Microbiota. Front. Microbiol. 2017, 8, 1562. [CrossRef]

121. Bijlsma, P.B.; van Raaij, M.T.; Dobbe, C.J.; Timmerman, A.; Kiliaan, A.J.; Taminiau, J.A.; Groot, J.A. Subchronic mild noise stress increases HRP permeability in rat small intestine in vitro. Physiol. Behav. 2001, 73, 43-49. [CrossRef]

122. Cui, B.; Su, D.; Li, W.; She, X.; Zhang, M.; Wang, R.; Zhai, Q. Effects of chronic noise exposure on the microbiome-gut-brain axis in senescence-accelerated prone mice: Implications for Alzheimer's disease. J. Neuroinflamm. 2018, 15, 190. [CrossRef] [PubMed]

123. Gue, M.; Peeters, T.; Depoortere, I.; Vantrappen, G.; Bueno, L. Stress-induced changes in gastric emptying, postprandial motility, and plasma gut hormone levels in dogs. Gastroenterology 1989, 97, 1101-1107. [CrossRef]

124. Ising, H.; Kruppa, B. Health effects caused by noise: Evidence in the literature from the past 25 years. Noise Health 2004, 6, 5-13. 
125. Kight, C.R.; Swaddle, J.P. How and why environmental noise impacts animals: An integrative, mechanistic review. Ecol. Lett. 2011, 14, 1052-1061. [CrossRef]

126. Liu, G.S.; Huang, Y.X.; Li, S.W.; Pan, B.R.; Wang, X.; Sun, D.Y.; Wang, Q.L. Experimental study on mechanism and protection of stress ulcer produced by explosive noise. World J. Gastroenterol. 1998, 4, 519-523. [CrossRef]

127. Miranda, S.; Roux, M.E. Acoustic stress induces long term severe intestinal inflammation in the mouse. Toxicol. Lett. 2017, 280,1-9. [CrossRef]

128. Mu, Z.B.; Huang, Y.X.; Zhao, B.M.; Liu, Z.X.; Zhang, B.H.; Wang, Q.L. Effect of explosive noise on gastrointestinal transit and plasma levels of polypeptide hormones. World J. Gastroenterol. 2006, 12, 2284-2287. [CrossRef]

129. Theodoroff, S.M.; Lewis, M.S.; Folmer, R.L.; Henry, J.A.; Carlson, K.F. Hearing impairment and tinnitus: Prevalence, risk factors, and outcomes in US service members and veterans deployed to the Iraq and Afghanistan wars. Epidemiol. Rev. 2015, 37, 71-85. [CrossRef]

130. Zhao, Y.; Jaber, V.; Lukiw, W.J. Secretory Products of the Human GI Tract Microbiome and Their Potential Impact on Alzheimer's Disease (AD): Detection of Lipopolysaccharide (LPS) in AD Hippocampus. Front. Cell Infect. Microbiol. 2017, 7, 318. [CrossRef]

131. Zhan, X.; Stamova, B.; Jin, L.W.; DeCarli, C.; Phinney, B.; Sharp, F.R. Gram-negative bacterial molecules associate with Alzheimer disease pathology. Neurology 2016, 87, 2324-2332. [CrossRef] [PubMed]

132. Lukiw, W.J. Bacteroides fragilis Lipopolysaccharide and Inflammatory Signaling in Alzheimer's Disease. Front. Microbiol. 2016, 7, 1544. [CrossRef] [PubMed]

133. Lin, L.; Zheng, L.J.; Zhang, L.J. Neuroinflammation, Gut Microbiome, and Alzheimer's Disease. Mol. Neurobiol. 2018, 55, 8243-8250. [CrossRef] [PubMed]

134. Kowalski, K.; Mulak, A. Brain-Gut-Microbiota Axis in Alzheimer's Disease. J. Neurogastroenterol. Motil. 2019, 25, 48-60. [CrossRef] [PubMed]

135. Itzhaki, R.F.; Wozniak, M.A.; Appelt, D.M.; Balin, B.J. Infiltration of the brain by pathogens causes Alzheimer's disease. Neurobiol. Aging 2004, 25, 619-627. [CrossRef] [PubMed]

136. Fox, M.; Knorr, D.A.; Haptonstall, K.M. Alzheimer's disease and symbiotic microbiota: An evolutionary medicine perspective. Ann. N. Y. Acad. Sci. 2019, 1449, 3-24. [CrossRef]

137. Zhou, Y.; Smith, D.; Leong, B.J.; Brannstrom, K.; Almqvist, F.; Chapman, M.R. Promiscuous cross-seeding between bacterial amyloids promotes interspecies biofilms. J. Biol. Chem. 2012, 287, 35092-35103. [CrossRef]

138. Walker, L.C.; Schelle, J.; Jucker, M. The Prion-Like Properties of Amyloid-beta Assemblies: Implications for Alzheimer's Disease. Cold Spring Harb. Perspect. Med. 2016, 6. [CrossRef]

139. Thevaranjan, N.; Puchta, A.; Schulz, C.; Naidoo, A.; Szamosi, J.C.; Verschoor, C.P.; Loukov, D.; Schenck, L.P.; Jury, J.; Foley, K.P.; et al. Age-Associated Microbial Dysbiosis Promotes Intestinal Permeability, Systemic Inflammation, and Macrophage Dysfunction. Cell Host Microbe 2017, 21, 455-466. [CrossRef]

140. Sochocka, M.; Donskow-Lysoniewska, K.; Diniz, B.S.; Kurpas, D.; Brzozowska, E.; Leszek, J. The Gut Microbiome Alterations and Inflammation-Driven Pathogenesis of Alzheimer's Disease-a Critical Review. Mol. Neurobiol. 2019, 56, 1841-1851. [CrossRef]

141. O'Toole, G.; Kaplan, H.B.; Kolter, R. Biofilm formation as microbial development. Annu. Rev. Microbiol. 2000, 54, 49-79. [CrossRef] [PubMed]

142. Pan, P.; Oshima, K.; Huang, Y.-W.; Yearsley, M.; Zhang, J.; Arnold, M.; Yu, J.; Wang, L.-S. Gut bacteria are required for the benefits of black raspberries in Apc ${ }^{\mathrm{Min} /+}$ mice. J. Berry Res. 2018, 8, 239-249. [CrossRef] [PubMed]

143. Jiang, B.; Zheng, S.; An, L.; Guo, J.; Asakawa, T. Changes in striatal dopamine transporter and tyrosine hydroxylase expression associated with fatigue and their reversal by blueberry juice. J. Berry Res. 2019, 9, 321-332. [CrossRef]

144. Woodward, G.; Kroon, P.; Cassidy, A.; Kay, C. Anthocyanin stability and recovery: Implications for the analysis of clinical and experimental samples. J. Agric. Food Chem. 2009, 57, 5271-5278. [CrossRef]

145. Welch, C.R.; Wu, Q.; Simon, J.E. Recent Advances in Anthocyanin Analysis and Characterization. Curr. Anal. Chem. 2008, 4, 75-101. [CrossRef]

146. Wallace, T.C.; Giusti, M.M. Anthocyanins. Adv. Nutr. 2015, 6, 620-622. [CrossRef]

147. Tedesco, I.; Carbone, V.; Spagnuolo, C.; Minasi, P.; Russo, G.L. Identification and Quantification of Flavonoids from Two Southern Italian Cultivars of Allium cepa L., Tropea (Red Onion) and Montoro (Copper Onion), 
and their Capacity to Protect Human Erythrocytes from Oxidative Stress. J. Agric. Food Chem. 2015, 63, 5229-5238. [CrossRef]

148. Samadi, A.K.; Bilsland, A.; Georgakilas, A.G.; Amedei, A.; Amin, A.; Bishayee, A.; Azmi, A.S.; Lokeshwar, B.L.; Grue, B.; Panis, C.; et al. A multi-targeted approach to suppress tumor-promoting inflammation. Semin. Cancer Biol. 2015, 3, S151-S184. [CrossRef]

149. Morais, C.A.; de Rosso, V.V.; Estadella, D.; Pisani, L.P. Anthocyanins as inflammatory modulators and the role of the gut microbiota. J. Nutr. Biochem. 2016, 33, 1-7. [CrossRef]

150. McGhie, T.K.; Walton, M.C. The bioavailability and absorption of anthocyanins: Towards a better understanding. Mol. Nutr. Food Res. 2007, 51, 702-713. [CrossRef]

151. Khoo, H.E.; Azlan, A.; Tang, S.T.; Lim, S.M. Anthocyanidins and anthocyanins: Colored pigments as food, pharmaceutical ingredients, and the potential health benefits. Food Nutr. Res. 2017, 61, 1361779. [CrossRef] [PubMed]

152. Junker, L.V.; Ensminger, I. Relationship between leaf optical properties, chlorophyll fluorescence and pigment changes in senescing Acer saccharum leaves. Tree Physiol. 2016, 36, 694-711. [CrossRef] [PubMed]

153. He, J.; Giusti, M.M. Anthocyanins: Natural colorants with health-promoting properties. Annu. Rev. Food Sci. Technol. 2010, 1, 163-187. [CrossRef] [PubMed]

154. Smeriglio, A.; Barreca, D.; Bellocco, E.; Trombetta, D. Chemistry, Pharmacology and Health Benefits of Anthocyanins. Phytother. Res. 2016, 30, 1265-1286. [CrossRef] [PubMed]

155. Kong, J.M.; Chia, L.S.; Goh, N.K.; Chia, T.F.; Brouillard, R. Analysis and biological activities of anthocyanins. Phytochemistry 2003, 64, 923-933. [CrossRef]

156. Fang, J. Bioavailability of anthocyanins. Drug Metab. Rev. 2014, 46, 508-520. [CrossRef]

157. Blando, F.; Calabriso, N.; Berland, H.; Maiorano, G.; Gerardi, C.; Carluccio, M.A.; Andersen, O.M. Radical Scavenging and Anti-Inflammatory Activities of Representative Anthocyanin Groupings from Pigment-Rich Fruits and Vegetables. Int. J. Mol. Sci. 2018, 19, 169. [CrossRef]

158. Zamora-Ros, R.; Knaze, V.; Lujan-Barroso, L.; Slimani, N.; Romieu, I.; Touillaud, M.; Kaaks, R.; Teucher, B.; Mattiello, A.; Grioni, S.; et al. Estimation of the intake of anthocyanidins and their food sources in the European Prospective Investigation into Cancer and Nutrition (EPIC) study. Br. J. Nutr. 2011, 106, 1090-1099. [CrossRef]

159. Umeda, K.; Matsui, T.; Nakayama, M.; Furuse, K.; Sasaki, H.; Furuse, M.; Tsukita, S. Establishment and characterization of cultured epithelial cells lacking expression of ZO-1. J. Biol. Chem. 2004, 279, 44785-44794. [CrossRef]

160. Turksen, K.; Troy, T.C. Barriers built on claudins. J. Cell Sci. 2004, 117, 2435-2447. [CrossRef]

161. Song, C.; Ring, L.; Hoffmann, T.; Huang, F.C.; Slovin, J.; Schwab, W. Acylphloroglucinol Biosynthesis in Strawberry Fruit. Plant Physiol. 2015, 169, 1656-1670. [CrossRef] [PubMed]

162. Sebastian, R.S.; Wilkinson Enns, C.; Goldman, J.D.; Martin, C.L.; Steinfeldt, L.C.; Murayi, T.; Moshfegh, A.J. A New Database Facilitates Characterization of Flavonoid Intake, Sources, and Positive Associations with Diet Quality among US Adults. J. Nutr. 2015, 145, 1239-1248. [CrossRef] [PubMed]

163. Morita, K.; Furuse, M.; Fujimoto, K.; Tsukita, S. Claudin multigene family encoding four-transmembrane domain protein components of tight junction strands. Proc. Natl. Acad. Sci. USA 1999, 96, 511-516. [CrossRef] [PubMed]

164. Monk, J.M.; Wu, W.; Hutchinson, A.L.; Pauls, P.; Robinson, L.E.; Power, K.A. Navy and black bean supplementation attenuates colitis-associated inflammation and colonic epithelial damage. J. Nutr. Biochem. 2018, 56, 215-223. [CrossRef]

165. Jezek, M.; Zorb, C.; Merkt, N.; Geilfus, C.M. Anthocyanin Management in Fruits by Fertilization. J. Agric. Food Chem. 2018, 66, 753-764. [CrossRef]

166. Feldman, G.J.; Mullin, J.M.; Ryan, M.P. Occludin: Structure, function and regulation. Adv. Drug Deliv. Rev. 2005, 57, 883-917. [CrossRef]

167. Bibi, S.; Kang, Y.; Du, M.; Zhu, M.J. Dietary red raspberries attenuate dextran sulfate sodium-induced acute colitis. J. Nutr. Biochem. 2018, 51, 40-46. [CrossRef]

168. Bartl, P.; Albreht, A.; Skrt, M.; Tremlova, B.; Ostadalova, M.; Smejkal, K.; Vovk, I.; Ulrih, N.P. Anthocyanins in purple and blue wheat grains and in resulting bread: Quantity, composition, and thermal stability. Int. J. Food Sci. Nutr. 2015, 66, 514-519. [CrossRef] 
169. Al-Asmakh, M.; Hedin, L. Microbiota and the control of blood-tissue barriers. Tissue Barriers 2015, 3, e1039691. [CrossRef]

170. Zhao, L.; Zhang, Y.; Liu, G.; Hao, S.; Wang, C.; Wang, Y. Black rice anthocyanin-rich extract and rosmarinic acid, alone and in combination, protect against DSS-induced colitis in mice. Food Funct. 2018, 9, 2796-2808. [CrossRef]

171. Zhang, C.; Monk, J.M.; Lu, J.T.; Zarepoor, L.; Wu, W.; Liu, R.; Pauls, K.P.; Wood, G.A.; Robinson, L.; Tsao, R.; et al. Cooked navy and black bean diets improve biomarkers of colon health and reduce inflammation during colitis. Br. J. Nutr. 2014, 111, 1549-1563. [CrossRef] [PubMed]

172. Sun, X.; Du, M.; Navarre, D.A.; Zhu, M.J. Purple Potato Extract Promotes Intestinal Epithelial Differentiation and Barrier Function by Activating AMP-Activated Protein Kinase. Mol. Nutr. Food Res. 2018, 62. [CrossRef] [PubMed]

173. Shan, Q.; Zheng, Y.; Lu, J.; Zhang, Z.; Wu, D.; Fan, S.; Hu, B.; Cai, X.; Cai, H.; Liu, P.; et al. Purple sweet potato color ameliorates kidney damage via inhibiting oxidative stress mediated NLRP3 inflammasome activation in high fat diet mice. Food Chem. Toxicol. 2014, 69, 339-346. [CrossRef] [PubMed]

174. Parkar, S.G.; Trower, T.M.; Stevenson, D.E. Fecal microbial metabolism of polyphenols and its effects on human gut microbiota. Anaerobe 2013, 23, 12-19. [CrossRef] [PubMed]

175. Hidalgo, M.; Oruna-Concha, M.J.; Kolida, S.; Walton, G.E.; Kallithraka, S.; Spencer, J.P.; de Pascual-Teresa, S. Metabolism of anthocyanins by human gut microflora and their influence on gut bacterial growth. J. Agric. Food Chem. 2012, 60, 3882-3890. [CrossRef] [PubMed]

176. Camelo-Mendez, G.A.; Agama-Acevedo, E.; Sanchez-Rivera, M.M.; Bello-Perez, L.A. Effect on in vitro starch digestibility of Mexican blue maize anthocyanins. Food Chem. 2016, 211, 281-284. [CrossRef]

177. Bialonska, D.; Ramnani, P.; Kasimsetty, S.G.; Muntha, K.R.; Gibson, G.R.; Ferreira, D. The influence of pomegranate by-product and punicalagins on selected groups of human intestinal microbiota. Int. J. Food Microbiol. 2010, 140, 175-182. [CrossRef]

178. Zhang, W.; Xu, J.H.; Yu, T.; Chen, Q.K. Effects of berberine and metformin on intestinal inflammation and gut microbiome composition in db/db mice. Biomed. Pharm. 2019, 118, 109131. [CrossRef]

179. Wisniewski, P.J.; Dowden, R.A.; Campbell, S.C. Role of Dietary Lipids in Modulating Inflammation through the Gut Microbiota. Nutrients 2019, 11, 117. [CrossRef]

180. Huang, H.Y.; Zhang, Z.J.; Cao, C.B.; Wang, N.; Liu, F.F.; Peng, J.Q.; Ren, X.J.; Qian, J. The TLR4/NF-kappaB signaling pathway mediates the growth of colon cancer. Eur. Rev. Med. Pharm. Sci. 2014, 18, 3834-3843.

181. Badshah, H.; Ali, T.; Kim, M.O. Osmotin attenuates LPS-induced neuroinflammation and memory impairments via the TLR4/NFkappaB signaling pathway. Sci. Rep. 2016, 6, 24493. [CrossRef] [PubMed]

182. McGeer, E.G.; McGeer, P.L. Inflammatory processes in Alzheimer's disease. Prog. Neuropsychopharm. Biol. Psychiatry 2003, 27, 741-749. [CrossRef]

183. Pratico, D.; Trojanowski, J.Q. Inflammatory hypotheses: Novel mechanisms of Alzheimer's neurodegeneration and new therapeutic targets? Neurobiol. Aging 2000, 21, 441-445. [CrossRef]

184. Pistollato, F.; Sumalla Cano, S.; Elio, I.; Masias Vergara, M.; Giampieri, F.; Battino, M. Role of gut microbiota and nutrients in amyloid formation and pathogenesis of Alzheimer disease. Nutr. Rev. 2016, 74, 624-634. [CrossRef]

185. Zhao, Y.; Lukiw, W.J. Microbiome-generated amyloid and potential impact on amyloidogenesis in Alzheimer's disease (AD). J. Nat. Sci. 2015, 1, e138.

186. Giau, V.V.; Wu, S.Y.; Jamerlan, A.; An, S.S.A.; Kim, S.Y.; Hulme, J. Gut Microbiota and Their Neuroinflammatory Implications in Alzheimer's Disease. Nutrients 2018, 10, 1765. [CrossRef]

187. Cerovic, M.; Forloni, G.; Balducci, C. Neuroinflammation and the Gut Microbiota: Possible Alternative Therapeutic Targets to Counteract Alzheimer's Disease? Front. Aging Neurosci. 2019, 11, 284. [CrossRef]

188. Khan, M.S.; Ali, T.; Kim, M.W.; Jo, M.H.; Jo, M.G.; Badshah, H.; Kim, M.O. Anthocyanins protect against LPS-induced oxidative stress-mediated neuroinflammation and neurodegeneration in the adult mouse cortex. Neurochem. Int. 2016, 100, 1-10. [CrossRef]

189. Zhao, L.; Chen, S.; Liu, T.; Wang, X.; Huang, H.; Liu, W. Callistephin enhances the protective effects of isoflurane on microglial injury through downregulation of inflammation and apoptosis. Mol. Med. Rep. 2019, 20, 802-812. [CrossRef]

190. Shukitt-Hale, B.; Kelly, M.E.; Bielinski, D.F.; Fisher, D.R. Tart Cherry Extracts Reduce Inflammatory and Oxidative Stress Signaling in Microglial Cells. Antioxid. Basel 2016, 5, 33. [CrossRef] 
191. Poulose, S.M.; Fisher, D.R.; Larson, J.; Bielinski, D.F.; Rimando, A.M.; Carey, A.N.; Schauss, A.G.; Shukitt-Hale, B. Anthocyanin-rich acai (Euterpe oleracea Mart.) fruit pulp fractions attenuate inflammatory stress signaling in mouse brain BV-2 microglial cells. J. Agric. Food Chem. 2012, 60, 1084-1093. [CrossRef] [PubMed]

192. Ma, H.; Johnson, S.L.; Liu, W.; DaSilva, N.A.; Meschwitz, S.; Dain, J.A.; Seeram, N.P. Evaluation of Polyphenol Anthocyanin-Enriched Extracts of Blackberry, Black Raspberry, Blueberry, Cranberry, Red Raspberry, and Strawberry for Free Radical Scavenging, Reactive Carbonyl Species Trapping, Anti-Glycation, Anti-beta-Amyloid Aggregation, and Microglial Neuroprotective Effects. Int. J. Mol. Sci. 2018, $19,461$. [CrossRef]

193. Khan, M.S.; Ali, T.; Kim, M.W.; Jo, M.H.; Chung, J.I.; Kim, M.O. Anthocyanins Improve Hippocampus-Dependent Memory Function and Prevent Neurodegeneration via JNK/Akt/GSK3beta Signaling in LPS-Treated Adult Mice. Mol. Neurobiol. 2019, 56, 671-687. [CrossRef] [PubMed]

194. Jeong, J.W.; Lee, W.S.; Shin, S.C.; Kim, G.Y.; Choi, B.T.; Choi, Y.H. Anthocyanins downregulate lipopolysaccharide-induced inflammatory responses in BV2 microglial cells by suppressing the NF-kappaB and Akt/MAPKs signaling pathways. Int. J. Mol. Sci. 2013, 14, 1502-1515. [CrossRef]

195. Chitnis, T.; Weiner, H.L. CNS inflammation and neurodegeneration. J. Clin. Investig. 2017, 127, $3577-3587$. [CrossRef]

196. Carey, A.N.; Fisher, D.R.; Rimando, A.M.; Gomes, S.M.; Bielinski, D.F.; Shukitt-Hale, B. Stilbenes and anthocyanins reduce stress signaling in BV-2 mouse microglia. J. Agric. Food Chem. 2013, 61, 5979-5986. [CrossRef]

197. Pugin, B.; Barcik, W.; Westermann, P.; Heider, A.; Wawrzyniak, M.; Hellings, P.; Akdis, C.A.; O’Mahony, L. A wide diversity of bacteria from the human gut produces and degrades biogenic amines. Microb. Ecol. Health Dis. 2017, 28, 1353881. [CrossRef]

198. Ali, T.; Kim, T.; Rehman, S.U.; Khan, M.S.; Amin, F.U.; Khan, M.; Ikram, M.; Kim, M.O. Natural Dietary Supplementation of Anthocyanins via PI3K/Akt/Nrf2/HO-1 Pathways Mitigate Oxidative Stress, Neurodegeneration, and Memory Impairment in a Mouse Model of Alzheimer's Disease. Mol. Neurobiol. 2018, 55, 6076-6093. [CrossRef]

199. Badshah, H.; Kim, T.H.; Kim, M.O. Protective effects of anthocyanins against amyloid beta-induced neurotoxicity in vivo and in vitro. Neurochem. Int. 2015, 80, 51-59. [CrossRef]

200. Pistollato, F.; Iglesias, R.C.; Ruiz, R.; Aparicio, S.; Crespo, J.; Lopez, L.D.; Manna, P.P.; Giampieri, F.; Battino, M. Nutritional patterns associated with the maintenance of neurocognitive functions and the risk of dementia and Alzheimer's disease: A focus on human studies. Pharm. Res. 2018, 131, 32-43. [CrossRef] 